\title{
The Case of the Prisoners and the Origins of Judicial Review
}

William Michael Treanor

Georgetown University Law Center, wtreanor@law.georgetown.edu

This paper can be downloaded free of charge from:

https://scholarship.law.georgetown.edu/facpub/1050

143 U. Pa. L. Rev. 491-570 (1994)

This open-access article is brought to you by the Georgetown Law Library. Posted with permission of the author. Follow this and additional works at: https://scholarship.law.georgetown.edu/facpub

Part of the Constitutional Law Commons, Courts Commons, Judges Commons, and the Legislation Commons 


\title{
THE CASE OF THE PRISONERS AND THE ORIGINS OF JUDICIAL REVIEW
}

\author{
William Michael TREanor $†$
}

\section{INTRODUCTION}

For over one hundred years, scholars have closely studied the handful of cases in which state courts, in the years before the Federal Constitutional Convention, confronted the question whether they had the power to declare laws invalid.' Interest in

† Associate Professor of Law, Fordham University; B.A., Yale College, 1979; A.M., Harvard University, 1982; J.D., Yale Law School, 1985.

I would like to thank the following people for their comments and suggestions: Akhil Amar, Marc Arkin, Deboral Denno, Jill Fisch, Martin Flaherty, James Fleming, Michael Gerhardt, Abner Greene, Tracy Higgins, Robert Kaczorowski, James Kainen, William Nelson, Russell Pearce, and Georgene Vairo. I am particularly grateful to Morton Horwitz for his invaluable guidance and advice on this project. Fordham Law School provided generous research support for this Article. Heather McCaffrey, Jenny Uber Kincaid, Chris St. Jeanos, and Frank Monaco supplied superb research assistance. I would also like to thank the Earl Gregg Swem Library at the College of William and Mary and the Library of Congress for the use of their manuscript collections, and, in particular, I would like to thank Margaret Cook of the Earl Gregg Swem Library for her extraordinary assistance in the use of the papers of St. George Tucker. Finally, I would like to thank the participants in the N.Y.U. Legal History Colloquium for their helpful reactions when this Article was presented at the Colloquium.

This Article is part of what will be a larger study of revolutionary-era judicial review cases. That study will use these cases to examine competing conceptions of constitutional interpretation and of judicial review prior to ratification of the Federal Constitution. It will also explore the extent to which judicial review was accepted (and opposed) in different states and the factors that contributed to these divergent responses.

${ }^{1}$ In 1953, Professor William Crosskey described nine revolutionary-era cases as comprising the "traditional list" of potential precedents for judicial review. 2 William W. Crosskey, Politics and the Constitution in the History of the UNITEd States 944 (1953). As Professor Suzanna Sherry has observed, "[Crosskey's] list of cases has not been improved upo $\rightarrow$ Suzanna Sherry, The Founders' Unwritten Constitution, 54 U. CHI. L. REV. 1127,1135 n.36 (1987).

Most of these nine cases do not appear in reporters, and in one instance it appears that a rumored decision did not in fact exist. Because of different interpretations of the evidence, scholars have claimed that as many as six of them are cases in which a court asserted the power to invalidate a statute, see CHARLES G. HAINES, THE AMERICAN DOCTRINE OF JUDICIAL SUPREMACY 88-121 (2d ed. 1959), and, at the other extreme, that none of these cases is a precedent for judicial review, see 1 LOUIS $B$. BOUdIN, GOVERNMENT BY JUDICIARY 51-72, 531-63 (1932). The following is, in chronological order, the "traditional list," including the reporter in which the case appears or, if it does not appear in a reporter, the published source or sources containing the fullest account of the case: Josiah Philips's Case (Va. 1778), described 
these early cases began in the late nineteenth century as one aspect of the larger debate about the legitimacy of judicial review, a debate triggered by the increasing frequency with which the Supreme Court and state courts were invalidating economic and social legislation. The lawyers, political scientists, and historians who initially unearthed the case law from the 1770 s and 1780 s used the product of their research to argue either that judicial review was sufficiently established at the time of the Federal Constitutional Convention so as to be part of the original understanding, even though the Constitution makes no mention of judicial review or, alternatively, that Marbury v. Madison ${ }^{2}$ was an act of judicial usurpation. ${ }^{3}$ In this century, scholars have continued to study these cases as part of that debate. ${ }^{4}$ More recently, the cases have been at the core of the

in 2 Crosskey, supra, at 944-48; 1 ST. George Tucker, Blackstone's CommentarIES: WITH NOTES OF REFERENCE TO THE CONSTITUTION AND LAWS OF THE FEDERAL Government of THE United States; ANd OF THE COMmONWEALTH OF Virginia bk. I, pt. 1, app. at 293 (1803); Holmes v. Walton (N.J. 1780), described in Austin Scott, Holmes v. Walton: The New Jersey Precedent, 4 AM. Hist. REv. 456 (1899); Commonwealth v. Caton, 8 Va. ( 4 Call) 5 (1782) (this case was contemporaneously known as the Case of the Prisoners and is the subject of this Article); Rutgers v. Waddington (N.Y. City Mayor's Ct. 1784), reprinted in 1 Julius GoEbel, JR., The LAW PrACTICE OF ALEXANDER HAMILTON: DOCUMENTS AND COMMENTARY 393-419 (1964); HENRY B.

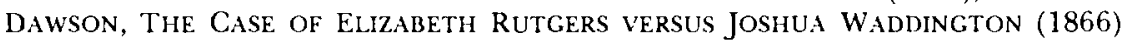
(providing a compilation of relevant materials); Symsbury Case, 1 Kirby 444 (Conn. Super. Ct. 1785); Trevett v. Weeden (R.I. 1786), described in JAMES M. VARnum, The Case, Trevet $v$. WeEden: ON Information and Complaint, for Refusing PaPer Bills in PAYMEnT for Butcher's MEAT, in MARKet, AT PAR with Specie (1787); "Ten-Pound Act" Cases (N.I. 1786), described in 2 CrosskeY, supra, at 968-71; Bayard v. Singleton, 1 N.C. (Mart.) 48 (1787). The ninth potential judicial review case, a Massachusetts case referred to in a letter from J.B. Cutting to Thomas Jefferson, appears to have never occurred; Cutting apparently misread a newspaper article describing one of the New I Iampshire "Ten-Pound Act" cases. See 2 CrosskeY, supra, at 961-62; $\Lambda$.C. Goodell, An Early Constitutional Case in Massachuselts, 7 HARv. I. REv. $415(1894)$.

25 U.S. (1 Cranch) 137 (1803).

${ }^{3}$ See Robert L. Clinton, Marbury v. Madison and Judicial Review 48-55, 166-75 (1989) (discussing late-19th-century examination of revolutionary-era judicial review cases and debate about judicial review). Among the most important books and articles from this period are the following: BRINTON COXE, AN ESSAY ON JUDICIAL POWER AND UNCONSTITUTIONAL LEgISLATION 216-71 (1893); 1 JAMES B. THAYER, CASES ON CONSTITUTIONAL LAW 55-80 (1895); Charles B. Elliot, The Legislalures and the Courts: The Power to Declare Statutes Unconstitutional, 5 POL. SCI. Q. 224, 233-39 (1890); Goodell, supra note 1; William M. Meigs, The Relation of the Judiciary to the Constitution, 19 AM. L. REv. 175 (1885); Scott, supra note 1; James B. Thayer, The Origin and Scope of the American Doctrine of Constitutional Law, 7 HARV. L. REv. 129, 131-40 (1893); William P. Trent, The Case of Josiah Philips, 1 AM. Hist. REv. 444 (1896).

+ For examples of 20 th-century studies of revolutionary-era cases, see RAOUL 
controversy over whether the original understanding permits the use of extraconstitutional sources, such as natural law, in judicial review. ${ }^{5}$

Given that judicial review in the revolutionary era is one of the most closely scrutinized subjects in legal history, it has long appeared that any significant primary sources from these cases had been analyzed. Indeed, it has been over forty years since a new source has been brought to bear on the study of revolutionary-era judicial review. ${ }^{6}$ Remarkably, however, there are two sets of

Berger, Congress $v$. The Supreme Court 36-46 (1969); 1 Boudin, supra note 1, at 51-72, 531-63; CliNTON, supra note 3, at 48-55; 2 CROSSKEY, supra note 1, at 938-75; 1 Julius Goebel, JR., History of the Supreme COURT of the United STATFs: ANTECEDENTS AND BECINNINGS TO 1801, at 125-42 (1971); HAINES, supra note 1, at 88-121; LEONARD W. LEVY, ORIGINAL INTENT AND THE FRAMERS' CONSTITUTION 89-99 (1988); SYLVIA SNOWISS, JUdicial REVIEW AND THE LAW OF THE CONSTITUTION 13-53 (1990); Shannon C. Stimson, The American Revolution in the Law 110-17 (1990); Charles Warren, Congress, The Constitution, and the Supreme Court 43-48 (1925); Gordon S. WoOd, The Creation of the American Republic, 1776 1787, at 453-63 (1969); L.B. Boudin, Government by Judiciary, 26 POL. SCI. Q. 238, 244 47 (1911); Edward S. Corwin, The Establishment of Judicial Review, 9 MICr. L. REv 102, 110-20 (1910); Report of the Committee upon the Duty of Courts to Refuse to Execute Statutes in Contravention of the Fundamental Law, 38 N.Y. ST. B. Ass'N PrOC. 230, 28087 (1915); Jesse Turner, A Phantom Precedent, 48 AM. L. REV, 321, 321-44 (1914); Jesse Turner, Four Fugitive Cases from the Realm of American Constitutional Law, 49 AM. L. RFv. 818, 818-51 (1915); Charles Warren, Earliest Cases of Judicial Review of State Legislation by Federal Courts, 32 YALE L.J. 15, 15-28 (1922).

${ }^{5}$ See, e.g., Calvin R. Massey, The Natural Law Component of the Ninth Amendment, 61 U. Cin. L. REv. 49, 63-73 (1992); Helen K. Michael, The Role of Nalural Law in Early American Constitutionalism: Did the Founders Contemplate Judicial Enforcement of "Unwritten" Individual Rights?, 69 N.C. L. REv. 421, $448-57$ (1991); Robert E. Riggs, Substantive Due Process in 1791, 1990 WIS. L. REv. 941, 977-80; Sherry, supra note 1, at $1134-46$.

${ }^{6}$ The last time a new primary source was first analyzed was 1952, when David Mays discussed Edmund Pendleton's notes in the Case of the Prisoners in the context of his account of the case in his biography of Pendleton. See 2 DAVID J. MAYS, EDMUnd PENDleton, 1721-1803: A BIOGRAPHY 187-202 (1952). Mays subsequently published Pendleton's notes. See Edmund Pendleton, Pendleton's Account of "The Case of the Prisoners, "in 2 The LetTers AND PAPERs of EDMUnd Pendleton, 1734-1803, at 416-27 (David J. Mays ed., 1967). Crosskey made use of Pendleton's notes in their unpublished form. See 2 CrosskeY, supra note 1, at 958-60. They have been ignored, however, in a number of the most important recent accounts of revolutionary-era judicial review cases, all of which have placed exclusive reliance on Call's account. See CLINTON, supra note 3, at 49; SNOWISS, supra note 4, at 17-24, 33; WOOD, supra note 4, at 454-55; Sherry, supra note 1, at 1143-45. None of these accounts mentions the published notes. Sherry, in a footnote, states that Crosskey called into question Call's report, but she adds that Mays, in his biography, had used Pendleton's notes "to support Call's reporting." Id. at 1143-44 n.90. In fact, as indicated in the next section of this chapter, see infra part I, Call's and Pendleton's accounts differ dramatically, and, where they conflict, Mays invariably followed Pendleton. 
unpublished attorneys' notes that have been preserved in library collections of personal papers that have never been analyzed by scholars of judicial review: the notes of Edmund Randolph and of St. George Tucker in Virginia's 1782 Case of the Prisoners (which reporter Daniel Call entitled Commonwealth v. Caton ${ }^{7}$ when he published a report of the case in 1827). ${ }^{8}$ These notes are significant in part because their authors were to become major legal figures and their early thinking on judicial review is therefore of value to constitutional historians. As a member of the Federal Constitutional Convention, Randolph proposed the Virginia Plan, the principal source for the Federal Constitution, and he subsequently was the first United States Attorney General and, later, Thomas Jefferson's successor as Secretary of State. ${ }^{9}$ Although now largely forgotten, Tucker was a member of the Virginia Court of Appeals, a federal judge,$^{10}$ and, in the words of Dean Paul Carring-

7 Va. (4 Call) 5 (1782).

${ }^{8}$ See Edmund Randolph, Rough Draft of Argument in Respondent v. Lamb (the Case of the Prisoners) (original in 91 James Madison Papers, Manuscript Division, Library of Congress, Washington, D.C.) (copy on file with author); St. George Tucker, Notes of Oral Argument in the Case of the Prisoners (original in Papers of St. George Tucker, Manuscripts Department, Earl Gregg Swem Library, College of William and Mary, Williamsburg, Virginia) (copy on file with author).

It should be noted that, in addition to being overlooked by scholars of judicial review, these two sets of notes have been essentially overlooked by other scholars and neither lawyer's arguments for judicial review nor discussions of constitutional construction have been discussed in print. Randolph's notes were sent to Madison as an attachment to his letter to Madison of March 7, 1783. The notes were filed in Madison's Papers at the Library of Congress separately from the cover letter, which may explain why the notes have not been focused on earlier. The cover letter, unlike Randolph's notes, has been published. See Letter from Edmund Randolph to James Madison (Mar. 7, 1783), in 6 The PAPERS OF JAMEs MAdison 318, 318-19 (William T. Hutchinson \& William M.E. Rachal eds., 1969) [hereinafter MADISON PAPERS]. The accompanying editorial footnote has several sentences summarizing Randolph's conception of the Virginia Constitution as fundamental law, but says nothing about Randolph's position on judicial review or on how to construe a constitution. See William T. Hutchinson \& William M.E. Rachal, Notes to Letter from Edmund Randolph, in 6 MADISON PAPERS, supra, at $321 \mathrm{n} .8$. Prior to this Article, this brief note appears to be the only published discussion of any part of the contents of Randolph's notes.

Apparently, the only prior discussion of the argument in Tucker's notes is found in Charles Cullen's biography of Tucker. Cullen simply observed that Tucker "made a strong argument for ... judicial review" in the Case of the Prisoners, without stating what that argument was. Charles T. Cullen, St. George Tucker AND LAW IN VIRGINIA, 1772-1804, at 36 (1987).

${ }^{9}$ See JoHn J. REARdon, EdMUNd RANDOLPH: A Blocraphy 98-99, 189-91 (1974).

${ }^{10}$ See Cullen, supra note 8, at 189. 
ton, "arguably the most important American legal scholar of the first half of the nineteenth century." 11

Far more significant, however, is the fact that Randolph's and Tucker's notes are perhaps the best evidence that we have about how people at the time of the Constitution's drafting thought a court should construe a constitution, a subject of critical concern to originalists today. These notes are apparently the only surviving sources from the revolutionary era in which attorneys in a case in which a statute's validity was challenged discussed how to interpret constitutional provisions. Similarly, other than in the Case of the Prisoners, none of the judicial opinions of which we have a record confronts the issue of constitutional construction. The absence of consideration of this issue is not surprising because these cases primarily involved challenges to statutes based on violations of unwritten fundamental law, such as the traditional right to a jury, rather than on violations of written constitutions. ${ }^{12}$ Furthermore, as Professor Charles Lofgren has observed, " $[t]$ he members of the Philadelphia Convention were silent about how they expected the Constitution to be interpreted." ${ }^{13}$ Adding to the value of Randolph's and Tucker's analyses is the fact that they both argued out of personal conviction, rather than to advance the interests of a client. Tucker, appearing before the court as an amicus, was arguing for himself. More surprisingly, Randolph, although contending as state attorney general that the challenged statute should be upheld, informed the court that he was duty bound to

" Paul D. Carrington, The Revolutionary Idea of University Legal Education, 31 WM. \& MARY L. REV. 527, 540 (1990).

${ }^{12}$ See Sherry, supra note 1 , at $1135-46$ (discussing cases). The one case other than the Case of the Prisoners to turn clearly on a written constitution was Bayard $v$. Singleton, 1 N.C. (Mart.) 48 (1787), but the treatment of the conflict between statute and constitution was conclusory. The statute at issue barred property owners from bringing suit to recover land confiscated by the state. North Carolina's constitution guaranteed the right to a trial by jury. See N.C. CONST. of 1776 , art. XIV, reprinted in 5 Francis $\mathrm{N}$. ThORPE, The Federal and State CONSTItutions Colonial. Charters, and Other Organic laws of the States, Territories, and Colonies Now OR Heretofore Forming the UNITEd States of AMERICA 2788 (1909). Without analysis, the court asserted that the challenged statute and state constitution were in conflict because "by the constitution every citizen had undoubtedly a right to a decision of his property by a trial by jury." Bayard, 1 N.C. (Mart.) at 49.

${ }^{13}$ Charles A. Lofgren, The Original Understanding of Original Intent?, 5 Constitutional Commentary 77, 79 (1988); see also H. Jefferson Powell, The Original Understanding of Original Intent, 98 HARV. L. REv. 885, 904 (1985) ("[T] he Philadelphia framers did not discuss in any detail how they intended their end product to be interpreted ...."). 
disclose his personal belief that a statute could be declared unconstitutional. In short, neither set of notes reflects partisan bias.

For originalists, then, these notes are a uniquely valuable guide to background understandings of how the Constitution was to be interpreted. What makes them of dramatic significance for originalists is that, as this Article will show, the notes reflect views of constitutional interpretation that are at odds with leading modern scholarship on the original understanding of the Framers on matters such as the significance of original intent, the judicial obligation to follow constitutional text strictly, and the extent to which courts should defer to legislatures. Thus, this new evidence is not only the best evidence we have about constitutional construction at the time of the framing, but it directly challenges received notions about the original understanding of that subject. Given the importance of originalism to modern constitutional jurisprudence, this challenge has important current ramifications in terms of how the Constitution should be understood.

Apart from the specific value of these notes, the Case of the Prisoners-in which three condemned men claimed that Virginia's Treason Statute violated the state constitution-merits careful study because it was in all likelihood the earliest case in which an American court, after independence, faced the issue of whether it could declare a statute unconstitutional, and because the case provided the occasion on which an astonishing number of important figures were forced to confront that issue for the first time. Two of the judges, George Wythe and John Blair, joined Randolph as representatives of Virginia at the Federal Constitutional Convention. John Francis Mercer, one of the lawyers who, like Tucker, argued as an amicus in the case, attended the Convention as a delegate from Maryland. James Madison was also intimately familiar with the case. He corresponded with both Chancellor Edmund Pendleton, the presiding judge, and Randolph about the case and acquired Pendleton's notes of his opinion. After repeated requests from Madison, Randolph sent him a part of the rough draft of his argument. $^{14}$ To the extent, then, that the early cases deserve examination in order to determine what arguments concerning

${ }^{14}$ For the list of participants in the Constitutional Convention, see 3 THE RECORDS OF THE FEDERAL CONVENTION OF 1787, at 587-90 (Max Farrand ed., rev. ed. 1937). For discussion of the participants in the Case of the Prisoners, see infra part I. On the Case of the Prisoners as the first judicial review case, see infra note 212. 
judicial review the Framers were exposed to and what their reactions to those arguments were, the Case of the Prisoners is worthy of close focus; it is probable that no other case was so well-known to such a large group of Framers. To the extent that the early cases merit study in order to understand Marbury, the Case of the Prisoners is particularly worthy of attention: apparently present among the crowd that gathered in the courtroom to hear the decision was John Marshall, then a young Virginia lawyer. ${ }^{15}$

Part I of this Article draws on Randolph's and Tucker's notes as well as other primary sources, such as letters, government records, and Pendleton's notes, to provide a detailed account of the Case of the Prisoners. These records indicate that two of the eight judges on the court of appeals took the position that the court had the power to declare statutes unconstitutional-one of the judges being Marshall's former law professor, George Wythe-and these may have been the first American judges to take this position. Only one judge held that the court did not have this power, and the others did not reach the issue.

Part II discusses the relevance of the case to a number of critical originalist legal debates. Perhaps most significant is the case's bearing on the question whether the founding generation believed original intent relevant to constitutional interpretation. In the leading article on the topic, The Original Understanding of Original Intent, $\mathrm{H}$. Jefferson Powell argued that the original understanding was that the Framers' subjective intent was irrelevant. ${ }^{16}$ Understandably (given that he did not have access to Randolph's and Tucker's notes, the only surviving revolutionary-era legal documents that seriously examined the issue), Powell based his view of the background understanding animating the Framers on inferences from schools of interpretation that he believed available to the Framers, and he did not probe revolutionary-era case law. Tucker and Randolph, however, both appealed to original intent, and Tucker, more to the point, specifically invoked the subjective intent of the state constitution's framers. The case thus suggests that the Framers of the Federal Constitution had available to them a view of interpretation under which their subjective intent was directly relevant to constitutional construction.

${ }^{15}$ See Charles F. Hobson et al., Introduction to 5 THE PAPERs Of JOHN MARSHALL at xxiii, lvii-lviii (Charles F. Hobson et al. eds., 1974) [hereinafter MARSHALL. PAPERS].

${ }^{16}$ Powell, supra note 13. 
More broadly, where Powell argues that the only hermeneutic traditions available to the Framers were completely or predominantly focused on text, the Case of the Prisoners suggests that many of the founding generation were "anti-literalists" ${ }^{17}$ who believed constitutions should be interpreted in light of their spirit, even when the spirit was at odds with the text. Indeed, appeals to the spirit of the Virginia Constitution are central to the arguments advanced in the case and indicate that extraconstitutional sources (including, but not limited to, evidence of original intent) were considered relevant to constitutional interpretation.

At the same time, the Case of the Prisoners challenges the conclusion reached by scholars who argue that early theories of judicial review embodied a constrained conception of the judicial role. While Randolph's argument reflects a limited notion of judicial review, Tucker's argument rests on an expansive view of judicial review. His argument, in conjunction with subsequent Virginia case law, demonstrates the presence of an aggressive conception of judicial review in the early republic. This Article thus suggests that an activist approach to judicial review can claim originalist support. Professor Suzanna Sherry has previously provided originalist support for judicial activism, but her claim in this regard is that revolutionary-era judges applied natural law. ${ }^{18}$ In contrast, this Article delineates an expansive conception of the judicial role based on construction of a written constitution in accordance with its spirit. It therefore significantly contributes to the debate about the founding generation's understanding of the scope of judicial review by offering evidence of judicial activism grounded, not in natural law, but in a broad reading of a constitution. From the perspective of originalism, this claim is of signal importance since activist modern constitutional jurisprudence involves expansive readings of constitutional text, not applications of natural law. ${ }^{19}$

${ }^{17}$ The term is Professor Morton Horwitz's. See Morton J. Horwitz, The Constitution of Change: Legal Fundamentality Without Fundamentalism, 107 HARV. L. REV. 32, 49 (1993); see also William M. Treanor \& Gene B. Sperling, Prospective Overruling and the Revival of "Unconstitutional" Statutes, 93 Colum. L. REv. 1902, 1942-43 \& n.154 (1993) (discussing competing conceptions in ratification debates on the Constitution's flexibility).

${ }^{18}$ See Sherry, supra note 1 , at 1178.

${ }^{19}$ See id. ("The formal analysis of modern constitutional law is pervaded by the legacy of judicial positivism, which has all but eradicated notions of any link between constitutional law and natural law."). 
Finally, study of the Case of the Prisoners and its aftermath casts new light on the issue that, over one hundred years ago, lay at the core of the initial interest in the early cases and that continues to be the subject of sharp controversy-the legitimacy of Chief Justice Marshall's decision in Marbury. Marbury and Marshall have traditionally been viewed in the context of national constitutional history and national acceptance of judicial review. This Article argues that they can also profitably be viewed in the context of the constitutional history of Virginia, Marshall's home state. Much of the enduring debate about Marbury and Marshall's motives in the case-and particularly the question whether the Chief Justice embraced judicial review because he desired a way in which a Federalist Judiciary could control the Republican Executive and Congress-reflects the view that judicial review was not established in this country at the time of the Constitution's ratification. That view grows in part out of the fact that scholars have previously devoted much of their focus to the three cases which, before this Article, appeared to have generated the largest body of surviving primary source material: Rutgers $v$. Waddington, ${ }^{20}$ Trevett $v$. Weed$e n,{ }^{21}$ and Bayard v. Singleton..$^{22}$ In New York, Rhode Island, and North Carolina, the states in which these cases were decided, there was significant opposition to judicial review, suggesting a national pattern in which judicial review was highly contested. But the Case of the Prisoners and the subsequent history of judicial review in Virginia indicate that that statute did not fit that pattern. Although the court in the Case of the Prisoners did not hold a statute invalid, and therefore the case is not a precedent for judicial review in the legal sense, the reaction to the case shows that judicial review did not provoke serious controversy in the state. Moreover, after the Case of the Prisoners but before Marbury, the Virginia judiciary asserted the power to review statutes, and every speaker at the

${ }^{20}$ N.Y. City Mayor's Ct. 1784, reprinted in 1 GOEBEL, supra note 1, at 393-419.

${ }^{21}$ R.I. 1786, described in VARNUM, supra note 1.

${ }^{22} 1$ N.C. (Mart.) 48 (1787). The focus on these three cases can be traced back at least to Brinton Coxe's 1893 study: these were the three cases he treated in detail. See CoXE, supra note 3, at 223-69. More recently, Gordon Wood in The Creation of the American Republic 1776-1787, the most influential modern revolutionary-era constitutional history, also focused on these three cases in his treatment of judicial review. See WOOD, supra note 4, at 453-63. For examples of other studies treating these cases (or a subset of them) as the most relevant revolutionary-era cases, see Clinton, supra note 3, at 48-54; LEVY, supra note 4, at 93-99; STIMSON, supra note 4, at 110-17; Boudin, supra note 4 , at $245-47$. 
Virginia ratifying convention (including Marshall) who discussed the legitimacy of judicial review endorsed it.

This Article suggests that the structure of Virginia's political and legal culture was such that judicial assertions of the power to invalidate statutes were accepted as legitimate and that that culture helps explain why Virginia was the one state in which judicial review had won broad support well before Marbury. Apart from his politics, and apart from whether or not there was a consensus at the time of the framing in favor of judicial review, Marshall was predisposed to embrace judicial review because he was a product of that political and legal culture. To put it another way, in Marbury, the Chief Justice was applying the lesson that he had learned over twenty years before when he heard his former law professor's judicial opinion in the Case of the Prisoners, and he was ensuring that the national judiciary had a power that his state's judiciary had long exercised without challenge.

\section{THE CASE OF THE PRISONERS}

Facing execution for treason, the three petitioners in the Case of the Prisoners contended that they had received an effective pardon from the Virginia House of Delegates and that Virginia's Treason Act, which provided that an individual could be pardoned only with the approval of both the House of Delegates and the Virginia Senate, was void because it was contrary to the state constitution. This section traces the history of the case, from its background, through the arguments of the various attorneys who played a part in the case, the decision of the Virginia Court of Appeals-which, by a divided vote, ruled against the prisoners-and, finally, the aftermath of the case. In particular, this section will focus on the four legal analyses of which a detailed record has been preserved: the arguments presented by St. George Tucker and Edmund Randolph before the court of appeals and the opinions of Chancellor George Wythe (one of the two jurists to pronounce in favor of judicial review) and Chancellor Edmund Pendleton (who reserved the issue).

\section{A. Background}

As the Revolutionary War drew to a close, the Virginia state government began the systematic prosecution of Virginians who had been prominent supporters of the Crown during the war. In 1781, 
John Caton, James Lamb, ${ }^{23}$ and Joshua Hopkins, the three prisoners in the Case of the Prisoners, had assisted the British troops who temporarily controlled much of the southeastern part of the state. They were convicted of treason in separate trials held in Princess Anne County in May and June 1782, and they were then taken to Richmond for sentencing. ${ }^{24}$ There, on June 15, 1782, the Virginia General Court sentenced them to death. ${ }^{25}$

The three men petitioned the Virginia House of Delegates for a pardon. The House voted in favor of a resolution that the men "be and remain Pardoned of the offence of which they are attained," ${ }^{26}$ subject to the condition that they be banished from Virginia. ${ }^{27}$ It then submitted the resolution to the Virginia Senate for its concurrence, but the Senate voted against issuing the pardon. ${ }^{28}$

On the day that the sheriff was to hang Caton, Lamb, and Hopkins, the prisoners produced a copy of the House resolution, without any indication that the resolution had been forwarded to the Senate or that it had been rejected by that body. ${ }^{29}$ The prisoners claimed that the pardon was valid and entitled them to their immediate release. ${ }^{30}$ Given the absence of any indication as to how the Senate had treated the petition, the sheriff was apparently uncertain as to how to proceed. As Chancellor Pendleton put it in his notes on the case, the sheriff "prudently respited the Execution, but kept the Prisoners in Goal [sic], until the meeting of the General Court in October term." 31

This conjunction of events-the House's approval of a pardon, the Senate's refusal to concur, and the three men's desperate attempts to use the House action in order to save their livesobviously was not the product of a plan to create a judicial review test case. But the fact that the prisoners would implore the general

${ }^{23}$ In his report, Call states that Lamb's first name was John. See Commonwealth v. Caton, 8 Va. (4 Call) 5, 5 (1782). Contemporaneous accounts, however, uniformly indicate that the defendant's first name was James. See 2 MAYs, supra note 6, at 384 n.l.

${ }^{24}$ See 2 MAYS, supra note 6, at 188-89, 384 n.2.

${ }^{25}$ See id. at 189.

${ }^{26}$ Pendleton, supra note 6 , at 416.

${ }^{27}$ See Randolph, supra note 8, at 1-2.

${ }^{28}$ See Pendleton, supra note 6, at 416; Letter from Edmund Randolph to James Madison (July 18, 1782), in 4 MADISON PAPERS, supra note 8, at 422, 424.

${ }^{29}$ See Pendleton, supra note 6 , at 417 .

${ }^{30}$ See id.

${ }^{31}$ Id. 
court to overturn a statute was apparent well before arguments were heard. On July 18, 1782, Attorney General Randolph advised James Madison, "[a] late incident will probably try the fortitude of our judiciary, by calling upon them to say, whether a law, contrary to the constitution, is obligatory." 32

The Treason Act made it clear that an individual convicted of treason could only be pardoned with the consent of both houses of the legislature. That statute provided:

[T]he governor ... shall in no wise have or exercise a right of granting pardon to any person or persons convicted in manner aforesaid [including those convicted of treason], but may suspend the execution until the meeting of the general assembly, who shall determine whether such person or persons are proper objects of mercy or not, and order accordingly. ${ }^{33}$

Although subsequent developments showed that the statute was not free from ambiguity, the relevant state constitutional provision seemed to indicate that, in those circumstances in which the legislature decided to strip the governor of the pardoning power, power had to be vested in the House of Delegates alone, rather than in both houses concurrently. The clause stated:

[The governor] shall, with the advice of the Council of State, have the power of granting reprieves or pardons, except where the prosecution shall have been carried on by the House of Delegates, or the law shall otherwise particularly direct; in which case, no reprieve or pardon shall be granted, but by resolve of the House of Delegates. ${ }^{34}$

Thus, the state constitution, which had been framed in 1776 , seemed to provide that the House of Delegates alone had the power to pardon, while the statute, which had been enacted later that year, clearly established that a resolution by the House of Delegates was insufficient to effect a pardon and that the agreement of the Senate was also necessary.

When the general court convened in October 1782, Attorney General Randolph requested the issuance of a new order for the

${ }^{32}$ Letter from Edmund Randolph to James Madison (July 18, 1782), in 4 MADISON PAPERS, supra note 8 , at $422,424$.

${ }^{33}$ An Act Declaring What Shall Be Treason, 1776 Va. Acts ch. III, reprinted in 9 William W. HeNing, THE STATUTES at LARGE: BEING a COllection of All the LAWS OF VIRGINIA, FROM THE FIRST SESSION OF THE LEGISLATURE IN THE YEAR 1619, at $168(1821)$.

${ }^{34}$ Id. at $115-16$. 
execution of the three men. In response, counsel for the prisoners presented the resolution of the House of Delegates. Unlike the version given to the sheriff, this copy indicated that the House had sent the order to the Senate for its concurrence, and the parties stipulated that the Senate had rejected the pardon. Counsel for the prisoners argued that under the state constitution the pardon was valid. Randolph countered that under the governing statute both houses had to agree to a pardon and that the proffered resolution, because it lacked the consent of the Senate, was not an effective pardon. ${ }^{35}$ The general court was unsure how to resolve the question whether the act and the constitution were in conflict and, if they were, whether the court should recognize the pardon issued by the House of Delegates. Judge Peter Lyons stated that he would rather resign his judgeship than hold a statute unconstitutional. ${ }^{36}$ But his was a minority view. The initial reaction of the majority was to find in favor of the prisoners on constitutional grounds. "I am firmly persuaded," Randolph informed Madison, "that the general court, had the question been taken, would have pronounced the nullity of the law, as being against the constitution." ${ }^{37}$ The court, however, ultimately decided not to decide the matter at once, but to adjourn for further consideration of the issue. When it reconvened, the general court again decided not to decide: Rather than issuing an order, the court determined that in view of its " $[n]$ ovelty and difficulty" the case should be resolved by the highest court in the state, the Virginia Court of Appeals. ${ }^{38}$

${ }^{35}$ See Pendleton, supra note 6 , at 417.

${ }^{36}$ Ascription of this comment to Lyons is based on inference. In his opinion for the court of appeals, Wythe observed that "the other day" one of the judges had said that "he would sooner quit the bench" than hold a statute void as unconstitutional. Commonwealth v. Caton, 8 Va. (4 Call) 5, 8 (1782). Presumably, Wythe was referring to a statement made during the course of the general court's proceedings, since all the opinions in the court of appeals were delivered on the same day. Although there is apparently no record of the various opinions in the general court, all the general court members also sat on the court of appeals, and Lyons was the only general court judge to state that a court could not invalidate a statute. Thus, it appears likely that Lyons was the judge to whom Wythe was referring and that Lyons had made the comment when the case was before the general court. See 2 MAYs, supra note 6, at $385 \mathrm{n} .12$ (noting that $W y t h e$ surely referred to Lyons when he described the refusal of "one of the [general court] judges" to void an act of the Assembly).

${ }^{37}$ Letter from Edmund Randolph to James Madison (Oct. 26, 1782), in 5 MADISON PAPERS, supra note 8 , at 217, 217-18.

${ }^{38}$ Pendleton, supra note 6 , at 417. 


\section{B. The Court of Appeals and Initial Proceedings}

Established in 1779, the Virginia Court of Appeals was made up of the sitting judges of the various courts of the state. ${ }^{39}$ In 1782, its membership included the three chancellors of the court of equity, Edmund Pendleton, George Wythe, and John Blair; the judges of the general court, Chief Judge Paul Carrington and Judges Bartholomew Dandridge, Peter Lyons, and James Mercer; and Judge Richard Cary of the court of admiralty. ${ }^{40}$ As the senior judge of the highest court of the state, the court of equity, Pendleton presided. ${ }^{41}$

There appears to have been sharp debate in political and legal circles over how the court of appeals should resolve the question whether a court had power to pronounce a statute void as unconstitutional. The case "made such noise" before it was decided, Pendleton later wrote to Madison. ${ }^{42}$ While their efforts did not succeed, a group of legislators urged the creation of a joint legislative-judicial committee to consider whether a court could hold a statute unconstitutional and to define the powers of the judiciary and the legislature. These legislators also proposed the creation of a council of revision "to keep the legislature in futur[e] cases within its just limits." ${ }^{43}$ Apparently concerned that the court of appeals would invalidate the statute and that the legislature would then move to nullify the judiciary's action, Randolph welcomed this scheme as a way to avoid deadlock and turmoil. "[W]ithout an accommodation fou[n]ded upon a reasonable construction of the constitution," he wrote Madison, "the appeal must be made to the people." ${ }^{44}$ So widespread was discussion of the matter before the court of appeals that a shorthand way of describing judicial review

${ }^{39}$ See An Act Constituting the Court of Appeals, 1779 Va. Acts ch. XXII, reprinted in 10 HENING, supra note 33 , at 89,90 . For a discussion of the postrevolutionary Virginia court system, see Hobson et al., supra note 15 , at xxvii-xxxiii.

${ }^{40}$ See Caton, 8 Va. (4 Call) at 5 n.*. Ben Waller, the second judge of the court of admiralty, was entitled to sit on the court of appeals, but consistently refused to do so because of the travel involved. See Daniel Call, Bio-graphical Sketch of the Judges of the Court of Appeals, During the Period of this and the Succeeding Volumes of Reports, $8 \mathrm{Va}$. (4 Call) vii, xx-xxi (1833) (discussing Judge Waller).

${ }^{41}$ See Call, supra note 40, at vii-ix (discussing Judge Pendleton).

${ }^{42}$ Letter from Edmund Pendleton to James Madison (Dec. 9, 1782), in 5 MADISON PAPERS, supra note 8 , at $382,382$.

${ }^{43}$ Letter from Edmund Randolph to James Madison (Oct. 26, 1782), in 5 MADISON PAPERS, supra note 8, at 217, 218 (alteration by editors of Madison Papers).

${ }^{44} I d$. (second alteration by editors of Madison Papers). 
developed. In letters and news accounts alike it was described simply as "the great constitutional question. ${ }^{n 45}$

When the court convened on October 29, 1782, Pendleton scheduled argument for the $31 \mathrm{st}$, and he said that the judges were interested in the answers to three questions. The first was jurisdictional-whether the court of appeals could have jurisdiction in a criminal case. The other two questions concerned judicial review. Pendleton asked for a discussion of " $[w]$ hether a Court of Law could declare an Act of the Legislature void because it was repugnant to the Act for the Constitution of Government?" 46 He also asked for argument on whether the treason statute was "contrary" to the pardon clause in the constitution. ${ }^{47}$ To assist the members of the bench in their deliberations, Pendleton "expressed a Wish that the Gentlemen of the Bar, tho' not engaged as Counsel, would generally deliver their Sentiments upon the Questions then stated." 48

\section{Randolph's Argument}

When the court reconvened on October 31st, the first attorney to argue was Attorney General Randolph, appearing on behalf of the State. It was to prove a remarkable argument. After the case was over, he promised Madison, "[a]s soon as I have state[d] the case in full, you shall receive a copy." ${ }^{49}$ When he failed to fulfill his commitment promptly, Madison pressed him. "You will not forget a ... promise which your letter makes with respect [to] the case lately decided by the Court of Appeals," Madison reminded the Attorney General on November 19. ${ }^{50}$ On December 30, 1782, he wrote Randolph another letter, which concluded, "You have not I hope forgot your promise of the case agitated so much in Virga.

${ }^{45}$ See, e.g., Letter from Edmund Pendleton to James Madison (Nov. 8, 1782), in 5 MADISON PAPERS, supra note 8 , at 260, 261 ("The great constitutional question, as it was called in our papers ... ."); Letter from Edmund Randolph to James Madison (Nov. 2, 1782), in 5 MADISON PAPERS, supra note 8, at 230, 230 ("The great constitutional question, which was mentioned in my last letter . ..."); Letter from Edmund Randolph to James Madison (Oct. 26, 1782), in 5 MADISON PAPERS, supra note 8 , at 217,217 ("The great constitutional question which I mentioned to you (... $\left.{ }^{n}\right)$.

${ }^{46}$ Pendleton, supra note 6, at 417.

${ }^{17}$ Id.

${ }^{48}$ Id.

19 Letter from Edmund Randolph to James Madison (Nov. 8, 1782), in 5 MADISON PAPERS, supra note 8, at 262, 263 (alteration by editors of Madison Papers).

${ }^{50}$ Letter from James Madison to Edmund Randolph (Nov. 19, 1782), in 5 MADISON PAPERS, supra note 8, at 288, 290 (alteration by editors of Madison Papers). 
Mr. Pendleton's state of it has been recd. by Mr. [Joseph Jones, a fellow member of the Continental Congress from Virginia] and has increased my curiosity to see yours. ${ }^{71}$ Randolph responded on January 15, 1783: "I shall certainly transmit a state of the constitutional question and argument, as soon as a mass of papers, now before me, is reduced." 52 On February 7, 1783, Randolph sheepishly wrote:

Your favor by yesterday's post would increase my importunity for a transcript of your extract from Mr. J-s [Uefferson's)] remarks, if I could assign a better apology for not sending you a state of the great question, than you can for not sending the transcript. But circumstanced, as we are in the bosom of urgent business, we must do these works at leisure. ${ }^{38}$

Finally, on March 7, Randolph fulfilled his initial promise, after a fashion:

Inclosed is a part of my notes on the question before the court of appeals. Inaccurate as they are (for they were the first rude sketch $\&$ the second is lost) you must content yourself with them. The remainder which is equally interesting ... shall be sent to you by the next post, if I can transcribe in time. ${ }^{54}$

True to form, Randolph was evidently unable to "transcribe in time," and it appears that he never sent the remainder of his notes to Madison. The eleven pages that he sent-the first part of his initial draft of his argument-have never been published and have never been used by historians of judicial review. But they are the only evidence of what is one of the most striking aspects of the Case of the Prisoners: Advancing a position that was contrary to the

${ }^{51}$ Letter from James Madison to Edmund Randolph (Dec. 30, 1782), in 5 MADISON PAPERS, supra note 8 , at $472,474$.

${ }^{52}$ Letter from Edmund Randolph to James Madison (Jan. 15, 1783), in 6 MADISON PAPERS, supra note 8 , at 43,43 .

${ }^{53}$ Letter from Edmund Randolph to James Madison (Feb. 7, 1783), in 6 MADISON PAPERS, supra note 8, at 207, 207-08. Randolph apparently was referring to Jefferson's memorandum to the Marquis de Barbé-Marbois, on which Madison had made notes. While that memorandum has not survived, it apparently set forth Jefferson's view that the Virginia Constitution of 1776 was not a true constitution because the voters who had elected delegates to the convention that framed the constitution had not intended them to frame a constitution. See William $T$. Hutchinson \& William M.E. Rachal, Notes to Letter from Edmund Randolph to James Madison (Mar. 7, 1783), in 6 MAdison PAPERS, supra note 8, at 318, $320 \mathrm{n} .7$ (discussing Jefferson's memorandum).

${ }^{54}$ Letter from Edmund Randolph to James Madison (Mar. 7, 1783), in 6 MADISON PAPERS, supra note 8 , at 318,319 . 
prosecution's interest in upholding the statute, Randolph, the state attorney general, apparently argued that he believed that a court had the power to hold a statute void as unconstitutional. He contended that the statute and the constitution were not inconsistent, and that the House of Delegate's pardon was void because it was contrary to the statute. Thus, he argued that the court should not block the prisoners' execution. But the notes indicate that Randolph argued that, had the legislature passed a statute that was inconsistent with the constitution, the statute could be declared void. ${ }^{55}$

Randolph's notes are particularly arresting because they bear evidence of his personal struggle to determine whether judicial review was valid. Indeed, the revisions that he made to the notes as he was writing them suggest that, as he worked out the argument, he reversed his initial position against judicial review. Although the notes are incomplete, it is a fair inference that he did not in the remaining part oppose judicial review considering that in the Federal Constitutional Convention he was one of the handful of clear proponents of judicial review, ${ }^{56}$ listing among the desirable features of the Virginia Plan that the "natl Judiciary" would be one of the "Checks upon the Legv. and Ex. Powers. ${ }^{n 7}$ He repeated this stance in the Virginia ratifying convention, declaring, that " $[\mathrm{i}] \mathrm{f}$ Congress wish [sic] to aggrandise themselves by oppressing the people, the Judiciary must first be corrupted. ${ }^{58}$

${ }^{55}$ This Article assumes that Randolph's notes reflect the essence of the argument that he actually made before the Virginia Court of Appeals. Presumably, if there was any significant discontinuity, he would have commented on it in his letter forwarding the notes to Madison, yet he did not. It should be added, however, that Call's report states that Randolph argued that "the court were [sic] not authorized to declare [the statute] void." Commonwealth v. Caton, 8 Va. (4 Call) 5, 7 (1782). No further details are provided. Call's report, however, is apparently inaccurate with respect to the characterization of John Mercer's argument, see infra part I.F., and various judges' opinions, see infra part I.H. Moreover, the absence of details about Randolph's argument indicates Call did not have access to Randolph's notes.

${ }^{56}$ Scholars have sharply disagreed among themselves as to which members of the Federal Constitutional Convention endorsed judicial review. Taking a conservative approach, Levy counts six participants as advocates of judicial review. Randolph is one of the six. See LEVY, supra note 4, at 103.

571 THE RECORDS OF THE FEDERAL CONVENTION OF 1787, supra note 14, at 28. In addition, with respect to the proposal that Congress has the power to block state laws, Randolph suggested, as an accommodation to the small states, that states have the right to appeal congressional decisions to the national judiciary, which would have the power to hold congressional negatives "void." 3 id. at 56.

${ }^{58} 9$ THE DOCUMENTARY HISTORY OF THE RATIFICATION OF THE CONSTITUTION 1101 (John P. Kaminiski \& Gaspare J. Saladino eds., 1990) [hereinafter DoCUMENTARY 
In the notes, after stating the facts of the case, Randolph began his legal argument by attempting to show that the statute and the constitution were not in conflict. He started by articulating his premise that the rules appropriate for construing a constitution were different from those appropriate for construing a statute. "In the former," he wrote:

the liberality, necessary to catch its spirit, must be adopted.

In the latter, the masculine force of substantial sense is too often subjected to the petty tyranny of grammatical rule.

The cause of this distinction seems to be, that

1. the constitution describes general outlines only; whereas a law proposes the detail ... [crossed out material]

In a word, the constitution cannot avoid a generality of terms, lest it should omit a part of that infinity of combination, of which the affairs of society are capable-whereas a law touches single subjects only. ${ }^{59}$

Randolph then sought to show that the constitution-interpreted in accordance with the "principle of liberality"60-did not bar the Senate from participating in the pardoning process. Commenting on the fact that the constitution specifically provided the House of Delegates with the power to pardon in cases of impeachment, Randolph wrote, "[E]very argument which tends to the propriety of uniting [the Senate] in pardoning in these instances [of impeachments], will prove the great improbability of their exclusion being intended in any other." ${ }^{61}$ Randolph thus specifically invoked framers' intent. But, as his argument made clear, he was not appealing to any specific evidence of subjective intent. Rather, intent was to be determined by looking at the structure of government established by the constitution, the nature of the governmen-

HISTORY]. It should be added that, if Randolph, in the part of the notes that has not survived, did declare his opposition to judicial review, this Article's contention that judicial review won early acceptance in Virginia would not be undermined. That acceptance is amply evidenced by the fact that the decision in the Case of the Prisoners did not provoke controversy, that all the speakers in the state constitutional convention to take a position on judicial review were in favor of it, and by early state case law. See infra part I.I, II.B. That the Attorney General announced his support for judicial review in a case in which he was also urging that a statute be upheld simply highlights the larger phenomenon.

${ }_{59}$ Randolph, supra note 8 , at 3 . As will be discussed below, Randolph originally listed three points under this heading. He then crossed out the second and third. See infra text accompanying notes 75-76.

${ }^{60}$ Randolph, supra note 8 , at 4.

${ }^{61}$ Id. 
tal institutions implicated, and by what common sense would indicate the framers intended.

In advancing his argument, Randolph first attempted to show why, under the British Constitution, it was proper to deny the King the power to pardon in cases of impeachment. He sketched the monarch's broad powers, and then stated, "As often as this formidable being shall offend against his country, his servants are considered as his wicked advisers and must suffer. Were he then permitted to cast a shield over them in defiance of the prosecution of the people, their security against his tyranny would be greatly diminished." ${ }^{62}$

In contrast, Randolph saw no reason to bar the Virginia Senate from a role in granting pardons in cases of impeachment. He asked, "[I]s a Virginian Senate armed with these fangs or these horrors [which the King possessed]? Have they separate interests from the Delegates?" 63 He answered by noting that membership in the Senate was not hereditary, that the senators were elected by the people, that they could not originate bills or amend money bills, and that the senators were not "by their powers as much of aristocracy as would hang on an aspin [sic] leaf." ${ }^{4} 4$ He also noted that under the constitution the senators were clearly incapable of issuing pardons without the approval of the House of Delegates. Randolph concluded that "[i]n the eyes of political wisdom," the House of Delegates had no grounds to fear a Senate role in the pardoning power in cases of impeachment. ${ }^{65}$

If there was no reason to deny the Senate a role in pardoning in cases of impeachment, Randolph stated that "[s]till less is to be apprehended from their interference in other cases." ${ }^{66} \mathrm{He}$ did not develop this point at length, but simply argued that there was no reason why the case of treason was so unique that the Senate should not have a role in pardoning those convicted of it: "[Treason] strikes as deep into the happiness of the Senate as citizens, and their existence as a body. Their judgment will be as keen, and irritation vs. the offense as acute [as that of the House of Delegates]." 67

${ }^{62}$ Id. at 5 .

${ }^{69}$ Id. Randolph originally wrote: "Have they separate interests from the people?" He then crossed out "people" and wrote in "Delegates."
${ }^{6+}$ Id.
${ }^{65} I d$.
${ }^{66} I d$. at 6 .
${ }^{67}$ Id. 
"These considerations," Randolph wrote, "are designed to open the way for reconciling by construction the law with the constitution. For if [the constitution's] spirit opposes the exclusion of the Senate, its words must be free from ambiguity and decided, or cannot have the supremacy. ${ }^{68}$ In other words, Randolph believed that the constitution should be construed in light of the political philosophy underlying the document. When a statute was challenged on constitutional grounds, and the statute was consistent with the philosophy of the constitution, the statute was constitutional unless contrary to express and unambiguous constitutional dictates.

Randolph then proposed a series of ways in which the court could interpret the constitution so as to find the statute valid. The first "solution" he offered was that the court should treat the phrase "or the law shall otherwise particularly direct" in the pardon clause of the constitution as if it were in parentheses. ${ }^{69}$ Thus, the constitution would provide that, in the case of prosecutions conducted by the House of Delegates, only the House of Delegates could issue pardons. In the case of other prosecutions, the legislature could provide any method of pardoning that it desired..$^{70}$

"Perhaps a better interpretation," Randolph continued, was reading the constitutional clause to hold that the House of Delegates had to assent to a pardon, but not as holding it to bar the additional requirement that the Senate had to concur with the House. ${ }^{71}$ Finally, Randolph suggested that the Treason Act represented a determination by the House of Delegates that it wanted the Senate to participate in the pardoning process. The statute, rather than being a derogation from the power of the House of Delegates, merely embodied that body's decision as to how it wanted to exercise its pardoning power under the constitution. Randolph asked:

[S]hall the delegates be forbidden to call in assistance the judgment of the Senate? And if they have declared, that the pardon of treason is too important for their decision, what injury

\footnotetext{
${ }^{68}$ Id.

${ }^{69}$ Id. at 7.

${ }^{70}$ See id.

${ }^{71}$ Id.
} 
can arise from their admitting the Senate so far, as to say, that they will not pardon without their concurrence? ${ }^{72}$

Randolph then turned to the "two awful contemplations" that the court would be forced to consider if it rejected his contention that the statute and the constitution could be reconciled: "1. Is the treason law to be declared void, so far as it is repugnant to the constitution? 2. If it can be declared void, can any court of judicature pronounce its nullity? ?73 $^{\text {73 }}$

Randolph had seemingly already stated his position on these questions. At the start of his notes, in setting forth the position of the state in the case, Randolph asserted, "[I]n the volume of the law ... we believe to be written ... that, howsoever adverse the law which vests this [pardoning] power in the general assembly may be to the constitution, no court of judicature can pronounce its nullity. "74

Moreover, in comparing constitutions and statutes at the beginning of his notes, Randolph originally wrote that "the constitution is intended, as a rule for the governors-a law for the rule of the governed." $75 \mathrm{He}$ also wrote that "the constitution delegates to the legislature every power of the people, except that of opposition-a law only draws into action certain portions of that power. ${ }^{n 6}$ Both points suggest that the function of the constitution is merely hortatory, as far as the legislature is concerned, and that the constitution imposes no constraints on a legislature that wishes to disregard constitutional dictates. Thus, the legislature possesses "every power of the people," and the constitution is a "law" for the people, but merely a "rule" for the legislature. The only powers that the people retain are those of "opposition," presumably the powers to vote the legislature out or to revolt. This position paralleled Blackstone's view of parliamentary supremacy: the

${ }^{72}$ Id. at 8.

${ }^{73}$ Id. The first question, from its context, poses the question whether judicial review is legitimate. The logical subject of "declared" in the first question is the court, because it is the court that is to answer the question, "Is the treason law to be declared void, so far as it is repugnant to the constitution?" Randolph's second question appears to pose the jurisdictional issue raised in the case, which is not resolved in the part of the notes that survives. In other words, "If it can be declared void, can any court of judicature pronounce its nullity?" poses the question whether the general court alone can nullify a criminal statute or whether the court of appeals possesses that power as well.

${ }^{74}$ Id. at 2.

${ }^{75} \mathrm{Id}$. at 3 .

${ }^{76} \mathrm{Id}$. 
Virginia legislature, like the parliament, is the supreme law-giver. ${ }^{77}$

At some point, however, Randolph apparently decided to reject this position. In revising the draft, he lined out the two distinctions between statutes and the constitution just discussed. And, after he demonstrated that the legislation and the constitution were not inconsistent, he declared himself in favor of judicial review. It is unclear whether, as he began drafting his notes, Randolph originally intended to argue against judicial review. But as he eventually set forth his ideas on judicial review, he made clear that his position was not the position of the Commonwealth. In stating his initial rejection of judicial review, Randolph used the word "we." In setting forth his arguments in favor of judicial review, however, he carefully ascribed the position to himself. ${ }^{78}$

Randolph declared himself in favor of judicial review in a fashion that was both dramatic and that conveyed the difficulty that he felt in adopting this position. After having informed the court that, if it found the statute and constitution inconsistent, it would have to resolve the difficult questions whether a statute inconsistent with the constitution was void and whether any court had the power to so find, Randolph said:

Here let me pause.

But why pause?

Do I tremble at the decision of my own mind, that a law against the constitution may be declared void? or I [sic] do I dread the resentment of the court, when $I$ bear testimony against their competency to pronounce the invalidity of the law?

No! The revolution has given me a coat of mail for my defense, while I adhere to its principles. That bench too is reared on the revolution, and will arrogate no undue power.

I hold then, that every law against the constitution may be declared void. ${ }^{79}$

He told the court that his sense of duty led him to argue as he did. "On this head," he wrote, "you [are] perceiving that [I] argue in

${ }^{77}$ Blackstone maintained that "the supreme and absolute authority of the state . . is vested by our constitution" in Parliament. 1 WILliam BLACKSTONE, COMmentaries 147 (Edward Christian ed., Thomas B. Wait \& Co. 1807) (1765). For a more complete discussion of Blackstone's view of parliamentary supremacy, see generally

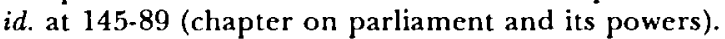

${ }^{78}$ See Randolph, supra note 8, at 9-11 (making reference to "I" and "me" when discussing judicial review).

${ }^{79}$ Id. at 9. 
favor of the criminals: my office does not extinguish that respect, which I shall owe to the constitution, as long as it remains such." 80

Randolph then expounded upon the significance of a constitution and what a constitution was. "Take a people," he began, "who have either never yet entered into a formal social compact, or having abolished an old one are about to conclude another." 81 Such a people would have differing ideas of how government should be structured and what their role in it was to be. One faction would desire "the uncontrouled command of an emperor." ${ }^{82}$ Another faction, "equally outrageous in their thirst for unlimited sovereignty, but conscious of their own individual capacity to govern, will form one common phalanx, and cry aloud for aristocracy," while some of this group "fancying themselves formed of purer clay, and enjoying a higher portion of aetherial spirit, than their companions, may rise to the claim of oligarchy." ${ }^{83}$ A third faction would seek "fair equality" and "the boisterous ocean of plebian rule," while a fourth faction, "more moderate-demonstrably more wise," would "labour for the erection of a system, sharing the good, and shunning the vices of the others." ${ }^{84}$

Randolph asked the court to imagine a legislature composed of members of these various factions:

[H] ow could laws, whose object is public happiness, be enacted subservient to this end, without a touchstone, by which to ascertain the degree of restraint or countenance, which may be given to each of the simple forms of government[?]

Without [a constitution] it cannot be decided how far the people, the fountain of power, have chosen to deposit it in the hands of their legislative servants, nor determine, when the right of resistance commences. ${ }^{85}$

To avoid legislative abuse of power and to avoid chaos, a constitution was necessary. Randolph defined a constitution as

[a] compact, in which the people themselves are the sole parties and which they alone can abrogate, delineating the degree, to which they have parted with legislative, executive and judiciary

\footnotetext{
${ }^{80} \mathrm{Id}$. at 11.

${ }^{81}$ Id. at 9 .

${ }^{82} I d$. at 10.

${ }^{83} \mathrm{Id}$.

${ }^{84} \mathrm{Id}$.

${ }^{85} \mathrm{Id}$. at $10-11$.
} 
power, as well as prescribing how far each of the simple forms of government is to be pursued in acts of legislation. ${ }^{86}$

Randolph's notes end abruptly as he turned to rebut a Blackstonian conception of legislative supremacy. They conclude: "That we have a constitution in my sense of the word, will not, I presume, be controverted-But an objection has been made against the permanency of a constitution from the changes, which laws have made in European governments, and especially in England." 87 The remainder of his notes has apparently not been preserved.

\section{Analysis of Randolph's Argument}

In light of then-reigning legal and political orthodoxies, Randolph's notes are a remarkable document in several respects (in addition to his use of original intent, which has already been noted and will be discussed in greater detail later). Most important, they very clearly set forth a vision of a constitution as an agreement among the people-a social compact. The classic English Whig conception of a constitution was the very different notion of an agreement between ruler and ruled. This Whig notion informed the rhetoric of the Revolution-the King, it was maintained, had violated his agreement with his people. ${ }^{88}$ This notion also informed constitution-making at the start of the revolutionary era. As Gordon Wood has written, the state constitutions "were still identified in the minds of many with their old colonial charters, as contracts between magistrates and people, defining and delimiting the powers and rights of each. ${ }^{89}$

By the time the Federal Constitution was ratified, the social compact conception of constitutions had displaced the notion of constitution as compact between ruled and ruler. Government had become a creature of the compact, rather than a party to it. ${ }^{90}$ This new conception, in turn, provided a basis for judicial review. Thus, on the eve of the constitutional convention, James Iredell argued that judicial review was proper because judges were merely ensuring that the legislature did not exceed the limits of the delegation of power that it had received from the people. ${ }^{91}$ Both Alexander

\footnotetext{
${ }^{86} I d$. at 11 .

${ }^{87} I d$.

${ }^{88}$ See WoOD, supra note 4 , at 268-70.

${ }^{89}$ Id. at 271.

${ }^{90}$ See id. at 600-01 (tracing the evolution of compact theory).

91 See James Iredell, To the Public (1786), in 2 GRIFFITH J. MCREE, LIFE AND
} 
Hamilton's Federalist No. $78^{92}$ and James Wilson's Lectures on Law, ${ }^{93}$ as well as Marbury, ${ }^{94}$ defend judicial review in similar fashion.

Randolph's notes suggest that he had come to a similar position earlier. Clearly, he thought of a constitution as a compact among the people-he explicitly stated as such in his definition of a constitution. Moreover, this conception of a constitution seems to have been underlying his position that "a law against the constitution may be declared void." 95 A constitution is a "touchstone"; the constitution allows the determination of "how far the people, the fountain of power, have chosen to deposit it in the hands of their legislative servants." ${ }^{\circ 6}$ Randolph seems to be moving toward the position that courts can review legislation for constitutionality because such review, rather than representing an aggrandizement of power by the judiciary, merely involves judicial enforcement of the boundaries created by the people when they adopted the constitution.

Like the notes of his argument, the letter that Randolph sent Madison along with his notes also bears witness to this notion of the constitution as a compact among the people that the legislature cannot legitimately violate. In that letter, Randolph took issue with

CORRESPONDENCE OF JAMES IREDELL 145, 145-46 (1857) (noting that the power of the legislature is constrained by the Constitution); Letter from James Iredell to Richard Spaight (Aug. 26, 1787), in $2 \mathrm{MCREE}$, supra, at 172 (elaborating on his theory of judicial review).

${ }^{92}$ THE FEDERALIST No. 78, at 464, 467-68 (Alexander Hamilton) (Clinton Rossiter ed., 1961). Hamilton noted:

There is no position which depends on clearer principles than that every act of a delegated authority, contrary to the tenor of the commission under which it is exercised, is void. ... [W] [Wenever a particular statute contravenes the Constitution, it will be the duty of the judicial tribunals to adhere to the latter and disregard the former.

Id.

93 1 THE WORKS OF JAMES WILSON 329-30 (Robert McCloskey ed., 1967). Wilson noted:

In consequence of [the Constitution], the bounds of the legislative power-a power most apt to overleap its bounds-are not only distinctly marked in a system itself; but effectual and permanent provision is made, that every transgression of those bounds shall be adjudged and rendered vain and fruitless.

Id.

94 5 U.S. (1 Cranch) 137, 175-80 (1803) ("If then the courts are to regard the constitution; and the constitution is superior to any ordinary act of the legislature; the constitution, and not such ordinary act, must govern the case to which they both apply.").

${ }_{95}$ Randolph, supra note 8 , at 9 .

${ }^{96} \mathrm{Id}$. at 11 . 
Jefferson's conception of the Virginia Constitution, a conception apparently enunciated in a memorandum to the Marquis de BarbéMarbois, a summary of which Randolph had received. Jefferson would later develop this conception in his Notes on the State of Virginia. ${ }^{97}$ Jefferson argued that the convention that framed the Virginia Constitution was elected at the start of the Revolutionary War for the sole purpose of governing the state; the people had not vested that convention with the power to enact a constitution, and future legislatures were therefore under no obligation to comply with the constitution that the convention enacted. Thus, Jefferson argued, statutes could legitimately contravene constitutional provisions. In addition, Jefferson pointed out that in the revolutionary era legislative transgressions on constitutional dictates were not only legitimate, they were frequent in occurrence. ${ }^{98}$ Rejecting these positions, Randolph wrote:

Mr. J-n has truly stated the modes, in which the Constitution was formed. But he ought to have added, that the people expected at the time of the election of the convention, that they were to be vested with power, of every sort, necessary for political happiness altho' perhaps independence was not a reigning opinion; that they confirmed it by executing it: and that the incroachments, made on it by the assembly, have proceeded either from inadvertency, or emergencies. For it is notorious that they constantly profess a sacred regard to the constitution. ${ }^{99}$

At the same time, Randolph did not suggest that the exercise of judicial review was a mechanical operation. In presenting his arguments to the court about the construction of the constitution's provision of pardoning, Randolph effectively acknowledged that the reading he was urging was not the only permissible one. He made clear that an ambiguous constitutional provision should be construed in light of the principles underlying the document as a whole and in recognition of the importance of giving effect to legislative pronouncements. Thus, he declared, "For if [the constitution's]

97 Thomas Jefferson, Noles on the Slate of Virginia (1787), reprinted in THOMAS JEFFERSON: WRITINGS 123 (Merrill D. Peterson ed., 1984).

${ }^{98}$ See Hutchinson \& Rachal, supra note 8 , at 320 n.7 (noting that “[d]uring the Revolution, the Virginia General Assembly had frequently transgressed [the constitution] and legally could have rescinded it altogether" ${ }^{m}$; Jefferson, supra note 97 , at 246-51 (adhering to the view that the Constitution could be altered by acts of the legislature).

${ }_{99}$ Letter from Edmund Randolph to James Madison (Mar. 7, 1783), in 6 MADISON PAPERS, supra note 8 , at $318,319$. 
spirit opposes the exclusion of the Senate, its words must be free from ambiguity and decided, or cannot have the supremacy. ${ }^{n 100}$

Such a statement reflects a conception of judicial review involving a marked degree of deference to the legislature. But Randolph's conception of judicial review was even more deferential than such a statement suggests, since the "ambiguity" in the constitution's pardoning provision was largely Randolph's handiwork. The constitutional clause seems to provide that where the executive was stripped of the pardoning power, the House of Delegates alone would have the power to pardon. Randolph created ambiguity by offering a number of strained readings of the constitutional text. As he privately admitted in one of his letters to Madison concerning the case, "I doubt not, that to any but lawyers the construction, by which the two [statute and constitutional provisions] were reconcile[d,] would appear unititelligible." 101

It may also be significant that Randolph decided not to be fully candid about the extent of deference that he thought appropriate in this case. In other words, he did not tell the court that he believed that a statute should be upheld if there were any reading of the constitution-no matter how strained and unintelligible to the layman-that would sustain it. This suggests that Randolph believed that it was important that statements of the principle of judicial review should not be too weak. Randolph appears to have thought for prudential reasons that the court should not overturn the Treason Act. Thus, when the decision was handed down, he wrote Madison that the court had avoided a determination whether a law could be declared void and that " $\mathrm{t}]$ here surely was prudence in the path, which they took." 102 But he also apparently believed that the legislature should not be granted tco wide a latitude, and that it was important not to acknowledge the extent to which prudential concerns would lead courts to uphold legislative actions inconsistent with constitutional provisions.

As they did with respect to the idea of a constitution, Randolph's notes indicate that he had moved away from the dominant modes of thought at the outbreak of the Revolution with

${ }^{100}$ Randolph, supra note 8 , at 6 .

${ }^{101}$ Letter from Edmund Randolph to James Madison (Nov. 8, 1782), in 5 MADISON PAPERS, supra note 8 , at 262, 263. Randolph was referring to the court's decision, but since the court adopted his reading, the comment is equally applicable to Randolph's own argument.

${ }^{102}$ Id. 
respect to faith in legislatures. At the start of the Revolution, Republican thinkers had believed that the legislature would be uniquely able to perceive and then advance the common good. ${ }^{103}$ Randolph's picture of the legislature is markedly different. For Randolph, in the absence of a constitution, the legislature would be comprised of advocates of tyranny, aristocratic rule, and mob rule; those who discern the common good and seek to take from various systems a new system "sharing the good, and shunning the vices of the others" are but one group among many. ${ }^{104}$ Governance by such a legislature would produce chaos and each undesirable system of government would leave its stamp on the polity: "[C]ivil institutions might be directed at different periods of the day to the support of the different principles of government .... This would leave a great multitude constantly murmuring and this mixture would give a truly pantomime govt to a code of laws." 105

Randolph never stated that the actual Virginia legislature was subject to the same weaknesses as his hypothetical legislature, but his meaning was clear: unless subject to constitutional checks, a state legislature would combine all the flaws that could characterize a government not subject to the checks imposed by balanced government. It would be, by turns, characterized by the worst aspects of mob rule, tyranny, and oligarchy, and would evidence a lack of stability.

In contrast, the bench was, in Randolph's view, dispassionate, above the fray, and able to act in accordance with the most valued principles of republican government. Thus, he stated, "the revolution has given me a coat of mail for my defense, while I adhere to its principles. That bench too is reared on the revolution, and will arrogate no undue power." 106

Randolph's acceptance of judicial review was thus based in significant part on his rejection of notions of institutional capacity that had animated the revolutionaries of 1776 . They had placed their faith in the legislature as a body capable of articulating and defending republican values, while denigrating the judiciary as

${ }^{103}$ See WOOD, supra note 4, at 162-73 (discussing early perceptions of representative legislatures); William M. Treanor, Note, The Origins and Original Significance of the Just Compensation Clause of the Fifth Amendment, 94 YALE L.J. 694, 701-02 (1985) (asserting that "[a]s the voice of the people, the legislature could be trusted to perceive the common good and to define the limits of individual rights").

${ }^{10+}$ Randolph, supra note 8 , at 10 .

${ }^{105} \mathrm{Id}$. at 11 .

${ }^{106} I d$. at 9. 
subject to the same antipopular tendencies as the executive. Randolph, in contrast, feared the legislature and placed his faith in the judiciary's adherence to revolutionary principles; this view is reflected in his embrace of judicial review. His willingness to concede the legitimacy in principle of judicial review in a case in which he was arguing to uphold a statute suggests a point that will be subsequently developed-judicial review early won surprisingly broad acceptance in Virginia.

\section{E. Argument for the Prisoners}

Andrew Ronald appeared on behalf of Caton, Lamb, and Hopkins. ${ }^{107}$ Ronald contended that the meaning of the constitution was clear: "[T] he power of pardoning belonged to the house of delegates." 108 He urged the court to reject Randolph's claim that the constitution's pardoning clause should be construed in light of framers' intent: “ $[\mathrm{T}]$ he words of the constitution, and not conjectures drawn from the supposed meaning of the framers of it, should give the rule." ${ }^{09}$ According to Ronald, judicial review of statutes was not only a proper judicial function, it compelled rejection of the treason statute. "[T] he act of assembly was contrary to the plain declaration of the constitution; and therefore void."110 Ronald also argued that to the extent that the constitution was ambiguous, "the construction ought, in favour of life, to incline to the side of mercy." 111

In addition, Ronald offered the court a way to resolve the case in favor of his clients without determining whether the exercise of judicial review was legitimate. He contended that the constitution's pardoning provision and the statutory pardoning provision were not inconsistent: both provisions made a separate grant of the pardoning power. Thus, the constitution gave the House of Delegates the power to pardon independently, while the treason statute gave the two houses of the legislature the power to pardon jointly. A par-

${ }^{107}$ In his reports, Call states that the cause of the prisoners was argued by ${ }^{4} \mathrm{Mr}$. Hardy and several other distinguished gentlemen." Commonwealth v. Caton, $8 \mathrm{Va}$. (4 Call) 5, 6 (1782). Mays speculates that the Mr. Hardy referred to was Samuel Hardy, a young Virginia lawyer. See 2 MAYS, supra note 6, at 194. Pendleton's notes state that Ronald was counsel for the prisoners. See Pendleton, supra note 6 , at 417.

${ }^{108}$ Caton, 8 Va. (4 Call) at 7.

${ }^{109} \mathrm{Id}$.

${ }^{110} I d$.

${ }^{111}$ Id. 
don granted in either fashion was valid. He analogized the case to a situation in which a right could be conferred by common law or by statute. The prisoners should have been released because they had secured a pardon in one of the two ways in which a pardon could be issued. ${ }^{112}$

\section{F. Amicus Advocates}

In addition to the representatives of the parties, the court heard from three men who responded to Pendleton's call for argument from interested members of the Virginia Bar: John Francis Mercer, brother of Judge James Mercer and a future member of Maryland's delegation to the Constitutional Convention; ${ }^{113}$ William Nelson, who later became a judge of the Virginia General Court and a professor of law at William and Mary; ${ }^{114}$ and the man who would eventually achieve the greatest eminence of the three, St. George Tucker. Tucker would become a member of the Virginia General Court, and then the court of appeals, a federal district court judge, and professor of law at William and Mary (where he was Wythe's successor and Nelson's predecessor). ${ }^{115}$ Most important, he was the editor and author of Blackstone's Commentaries: With Notes of Reference to the Constitution and Laws of the Federal Government of the United States; and of the Commonwealth of Virginia. ${ }^{116}$ This work included not only Tucker's notes on Blackstone's work, but lengthy appendices that he wrote on federal and state law. Charles Cullen, Tucker's biographer, has written:

Until the introduction of the case method of teaching law in the late nineteenth century commentaries and treatises were actually the only texts or references students and lawyers had for studying American law, and St. George Tucker's Blackstone was the only summary of similar dimensions available until Chancellor James Kent of New York began publishing his Commentaries on American

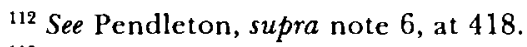

${ }^{113}$ See Biographical Directory of the United States CONGRess, 1774-1989, S. Doc. No. 34, 100th Cong., 2d Sess. 1490-91 (1989).

${ }^{114}$ See Carrington, supra note 11, at 540-41.

${ }^{115}$ See CULLEN, supra note 8, at 188-89. Cullen's biography is the most detailed scholarly study of Tucker's career, although it ends with his appointment to the Virginia Court of Appeals. See generally MARY COLEman, St. GeORGe TuCKer: CITIZEN OF NO MEAN CITY (1938) (biography focusing on Tucker's personal life).

${ }^{116}$ See TUCKER, supra note 1. 
Law in 1826. No other American edition of Blackstone could compare with Tucker's until $1852 \ldots$. $^{117}$

Until the appearance of Kent's Commentaries, Tucker was the commentator most frequently cited by the Supreme Court and the counsel who appeared before it. ${ }^{118} \mathrm{He}$ became known as the "American Blackstone." 119

Call indicates that all the lawyers who appeared as amici argued on behalf of the prisoners. ${ }^{120}$ Pendleton states that these lawyers "differ[ed] amongst themselves in several points, particularly as to the Power of the Court to declare an Act of Assembly void in any case. $^{n 21}$ It appears that Nelson and Tucker, at least, both argued in favor of judicial review. Apart from the brief summaries in Call's and Pendleton's accounts, the only apparent surviving record of any of the amici's arguments is Tucker's notes. Tucker's notes, which will be discussed below, make clear that he argued in favor of the prisoners and in favor of judicial review. The notes are in the form of a letter "To W. N. Esq." and Tucker indicated in the margin that they were originally prepared as an argument to be read by "my friend Wm. Nelson who proposed to appear in behalf of the prisoners." 122 Apparently, when Tucker arrived in Court, he found that Nelson had already drafted his own comments. Nelson suggested that Tucker deliver his own remarks, and the latter did. ${ }^{123}$ Presumably, then, Tucker and Nelson were in essential agreement on the positions that they took. Mercer, in contrast, likely argued against judicial review since, when he attended the Federal Constitutional Convention as a Maryland representative, he stated that " $[\mathrm{h}] \mathrm{e}$ disapproved of the Doctrine that the Judges as expositors of the Constitution should have authority to declare a law void. He thought laws ought to be well and cautiously made, and then to be uncontroulable." ${ }^{24}$

117 CULLEN, supra note 8, at 162.

${ }^{118}$ See id. at $163 \&$ n.77 (noting that Tucker's Blackstone was cited 19 times in opinions and arguments by counsel).

${ }^{19} \mathrm{~J}$. Randolph Tucker, The Judges Tucker of the Court of Appeals of Virginia, 1 VA.

L. REG. 789, 793 (1896).

${ }^{120}$ See Commonwealth v. Caton, 8 Va. (4 Call) 5,5 (1782).

${ }^{121}$ Pendleton, supra note 6 , at 418 .

${ }^{122}$ Tucker, supra note 8 . This comment is on the jacket of the notes.

${ }^{129}$ See id.

${ }^{124} 2$ The ReCORdS Of THE FEdERAL CONVENTION OF 1787, supra note 14, at 298. 


\section{G. Tucker's Argument}

Tucker's notes are, with Randolph's, apparently the oldest surviving revolutionary-era document discussing judicial review, and the complexity and detail of the analysis make Tucker's notes of particular value as an historical document. Unlike Randolph's, Tucker's argument is fully preserved. Also unlike Randolph, Tucker did not advance a conception of judicial review that reflected judicial deference to the legislature. Tucker's argument merits recognition as being of intellectual force equal to the famous defenses of judicial review that James Iredell, ${ }^{125}$ Alexander Hamilton, ${ }^{126}$ and James Wilson ${ }^{127}$ were subsequently to develop. The two aspects of his argument that merit particular scrutiny are his justification for judicial review and his conception of constitutional construction.

Tucker began by invoking the provision of the Virginia Bill of Rights under which "the Executive and Legislative powers of the state should be separate and distinct from the Judiciary" and the parallel provision of the state constitution barring each branch from exercising the powers of another. ${ }^{128}$ The relevant question thus became what the judicial function was. Tucker did not, however, treat this subject as one over which people could differ. "Now I hold it to be uncontrovertible," he said, "that the power properly belonging to the Judiciary Department, is, to explain the Laws of the Land as they apply to particular cases. ${ }^{129}$ That this power of applying the laws to specific cases was vested exclusively in the judiciary was a necessary restraint on legislative tyranny. $\mathrm{He}$ invoked Montesquieu for the proposition that "the same Man or body of men should not enact Lavs, or afterwards carry them into execution, for in this case [Montesquieu] observes arbitrary Laws may first be made and then tyrannically executed, or interpreted." ${ }^{130}$ "[T]his," Tucker added, "is also the spirit of our Constitu-

${ }^{125}$ See Iredell, supra note 91; Letter from James Iredell to Richard Spaight (Aug.

26, 1787), in 2 MCREE, supra note 91 , at 172.

${ }^{126}$ See THE FEDERALIST No. 78, supra note 92.

${ }^{127}$ See 1 THE WORKS OF JAMES WILSON, supra note 93, at 329-30. Wilson lectured that it is the right and duty of a court of justice to void any legislative act repugnant to the constitution.

${ }^{128}$ Tucker, supra note 8 , at 2-3.

${ }^{129}$ Id. at 3.

${ }^{130}$ Id. at 4. 
tion. ... [T]he Judiciary . . . are by the Constitution appointed as a counterpoise to [the legislature]." ${ }^{131}$

Having developed the proposition that application of the law to individual cases was an exclusively judicial function, Tucker asserted "it follows that [the judiciary] alone (if any of the Departments of Government can do it) can decide what is or is not Law, and consequently (I should presume) on the validity or nullity of different Laws contradicting each other. ${ }^{132}$ When the conflict was between a statute and the constitution, the constitution had precedence because it was the "Bulwark of the Liberties of the Citizens of this Commonwealth . . . as framed agreeable to their Bill of Rights which is declared to be the Basis and Foundation of Government. ${ }^{133}$ Tucker continued:

Under this Idea I conceive the Constitution not lyable to any alteration whatsoever by the Legislative, without destroying that Basis and Foundation of Government.

For altho' it be true that the Judges are sworn to decide in all matters brought before them agreeably to the Laws of the Land, yet as the Constitution [is] the first Law by which they are bound, and any Decision contrary thereto is absolutely subversive of that Government of which it is undoubtedly the Basis and Foundation. ${ }^{134}$

This part of his argument for judicial review is based on a separation of powers theory. Judicial review is justified as simply an exercise of the judicial function of deciding what law to apply to a particular case. In other words, when the constitution and a statute dictate different results in a case, the court must choose between them, and its first obligation is to the constitution.

Significantly, this separation of powers argument has two different and independent bases. One is Montesquieu, and the other is the state constitution. Tucker invokes Montesquieu as standing for the general proposition that it invites tyranny to have the lawmaker also be the law interpreter. ${ }^{135}$ The most important

${ }^{131} I d$.

${ }^{192} I d$. at 5.

${ }^{139} I d$. at 6.

${ }^{134} \mathrm{Id}$.

${ }^{135}$ Tucker did not cite a specific section of Montesquieu, but his reference is presumably to the chapter in The Spirit of the Laws on the English Constitution, the chapter that most profoundly influenced the Framers of the United States Constitution. See M.J.C. Vil.E, ConstitutJonalism and the SEParation of POWERS 84-86 
point to recognize about this argument is that it is extraconstitutional: it indicates that judicial review would be appropriate even in the absence of constitutional text providing for separation of powers.

The alternative separation of powers argument-the constitutional argument-draws on very open-ended constitutional text. Tucker's reference to the Virginia Bill of Rights is a reference to section five, which states in relevant part: "That the Executive and Legislative powers of the state should be separate and distinct from the Judiciary. ${ }^{136}$ Since the concept of the judiciary as a separate branch of government was relatively novel, ${ }^{137}$ the term "Judiciary" did not have a fixed meaning. Tucker's statement, "This is also the Spirit of the Constitution, ${ }^{138}$ implicitly recognizes this with its invocation of the "spirit," not the letter, of the constitution.

Tucker acknowledged that Parliament was not constrained by the British Constitution, but stated, "[N]o parallel can possibly be drawn between the Constitution of [Great Britain] and this Country. ${ }^{139}$ The Magna Carta, the Habeas Corpus Act, and the British Bill of Rights were all "constitutional acts," but they "have been altered by the British Parliament, more than once." 140 Such alteration reflected the fact that

some of the ablest Politicians of that nation [Great Britain] considered [these statutes] only as Acts explanatory of that Constitution, which has existed to use their own phrase from times beyond the memory of man; and that all the Rights and Priviledges [sic] therein set forth were the inherent and indefeasible Rights of Englishmen equally as if those Acts explaining them had never been made. ${ }^{141}$

Under this view, since the constitutional acts were considered merely declaratory of the constitution, parliamentary amendment of

(1967) (discussing Montesquieu's chapter on the English Constitution and its effect on the evolution of the separation of powers doctrine). In that chapter-which is chapter 6 of part 2, book 11-Montesquieu wrote: "Nor is there liberty if the power of judging is not separate from legislative power. . . If it were joined to legislative power, the power over the life and liberty of the citizens would be arbitrary, for the judge would be the legislator." Charles de Secondat MONTESQUieu, THE SPIRIT OF THE LAws 157 (Anne M. Cohler et al. eds. \& trans., 1989) (1748).

${ }^{136} \mathrm{VA}$. CoNST. of 1776 , art. $\mathrm{l}, \S 5$.

${ }^{137}$ See WOOD, supra note 4, at 159-60.

${ }^{138}$ See supra text accompanying note 131.

I39 Tucker, supra note 8 , at 7 .

${ }^{140} \mathrm{Id}$.

${ }^{141}$ Id. at 7. 
them was seen as merely correcting previous misstatements about the meaning of the constitution. An alteration of one of the constitutional statutes "is only considered as placing what really was the Constitution in it's [sic] proper light." ${ }^{142}$ Tucker added that the view that Parliament was not thereby altering the British Constitution was a "Fiction in Law," noting that "the British Constitution may be modelled agreeably to the will of Parliament, whose omnipotence in this Instance seems generally admitted. ${ }^{n 143}$

Tucker contrasted the Virginia Constitution with the British Constitution. The two were different in every critical aspect:

[T] ] Be British is constructive-Ours is express-the British is traditional; and different points of it have been explained at different times, and by different parliaments and in different modes. Ours on the contrary was framed with all the solemnity of an original Compact between the Citizens about to establish a Government most agreeable to themselves. That it might not be liable to be infringed it is founded on a Bill of Rights which is declared to form the Basis and Foundation of Government; and that it might not be misinterpreted it was committed to writing and made public to all the Citizens who became parties thereto. ${ }^{144}$

The British Constitution evolves and is subject to judicial reinterpretation. In contrast, the Virginia Constitution was for Tucker, as it was for Randolph, the original compact. For Tucker, one implication that followed from the Virginia Constitution's status as original compact was that its meaning was fixed.

This stress on the constitution as original compact exists in tension with the Montesquieu-based argument for separation of powers. The former rests on the notion that the basis of law is positivist: law, and specifically constitutional law, is created by the people as they enact the original compact. To the extent that it is based, not on the constitution, but on the principle that it risks tyranny to have the lawmaker be the law-interpreter, the separation of powers argument indicates that there is a source of law external to the positivist constitution: judges are empowered to review statutes, not because the people have given them that power, but because they must do so if liberty is to be preserved.

${ }^{142}$ Id. at 8 .

${ }^{143}$ Id.

${ }^{14} I d$. at $8-9$. 
Having offered his explanation of the nature of the Virginia Constitution, Tucker stated, without apparently feeling the need for elaboration or defense, that the judiciary was entrusted with the protection of the constitution: "Here then [in the constitution] are explained those Fundamental Principles of our Government, of which the Judiciary Department is constituted the Guardian."145 Tucker's language here is significant. His choice of the word "Guardian" suggests that protection of the constitution is a peculiarly judicial role, rather than a responsibility shared among the branches.

The point that troubled Jefferson-the fact that the convention that enacted the Virginia Constitution had not been elected for that purpose-was not addressed by Tucker, but he did offer two explanations for why the legislature's acts were subject to constitutional limits. First, since the legislature was the creature of the constitution, it logically did not have the authority to alter the document that called it into being: "For the Constitution being the Act of the political Legislature and in nature of an original Compact between the Citizens of the Commonwealth ... an inferior or subordinate Institution can not have power to annul or avoid any part of the Constitution so established." ${ }^{146}$ Second, the people did not understand the legislature to have the power to act in a way that was inconsistent with the constitution: "[T] here is no proposition in nature more generally admitted, than the Opinion is received [sic] in this Commonwealth, that no General Assembly can alter, repeal or annul a single Iota of the Constitution. ${ }^{147}$ As a result, any legislative act that was "repugnant" to the constitution was "ab initio void." 148

After establishing that the constitution was superior to statutes and that the judiciary was the guardian of the constitution, Tucker turned to the question whether the Treason Act "be consistent with or repugnant to the Constitution." ${ }^{149} \mathrm{He}$ candidly informed the court, "Here my embarrassment is excessive on many Accounts-I

${ }^{145}$ Id. at 9.

${ }^{146}$ Id. at $9-10$.

${ }^{147}$ Id. at 10; see also id. ( ${ }^{\text {[ }}[\mathrm{T}]$ he universal concurrence of Opinion in the Citizens of the Commonwealth [is that] Any General Assembly convened for the purposes of civil Legislation only [does not have] the right of altering, repealing or annulling the Constitution.").

${ }^{148} I d$.

${ }^{149}$ Id. at 11. 
have never seen the Treason Law." 150 Earlier in his argument, Tucker had made clear that a statute would be unconstitutional only if it were dramatically at odds with the constitution, stating that the constitution "is the touchstone by which every Act of the Legislature is to be tried. If any Act thereof shall be found absolutely and irreconcilably contradictory to the Constitution, it can not admit of a Doubt that such act is absolutely null and void. ${ }^{n 151}$ Tucker continued:

I [am not] competent to decide so nice a point as that which this Question [of the statute's constitutionality] includes. Yet the reasons offered, as I am informed, by an honourable member of the G.C. that it was the Intention of the Constitution to have as few Obstacles as possible in the way to mercy-and some other parts of the constitution by which it appears that particular exclusive Privileges have been reserved to the honour of the house of Delegates-have induced me to incline to the Opinion that the spirit of our Constitution declares that the power of pardoning in all cases where it is not given to the Executive is vested in the House of Delegates alone. ${ }^{152}$

Tucker, in resolving a question of a statute's constitutionality, looked beyond the express limitations established by the constitutional text. Just as he had invoked the "spirit" of the constitution in support of the notion of judicial review, now Tucker asserted that a statute could be unconstitutional because it was inconsistent with the "spirit" of the constitution. This broad notion of judicial review accords with Tucker's notion of the judiciary as the "Guardian" of the constitution.

In locating the "spirit," Tucker looked beyond the constitutional text and considered contemporaneous testimony about intent as well as constitutional structure. Like Randolph, therefore, Tucker employed an argument from intent to support his position. But Randolph used intent to mean what logic and considerations of structure suggested that the framers intended. As Andrew Ronald, the attorney for the prisoners, accurately (if unsympathetically) summarized Randolph's approach, it involved "conjectures drawn from the supposed meaning of the framers." 153 Tucker, in contrast, cited specific extra-textual evidence of the framers' intent,

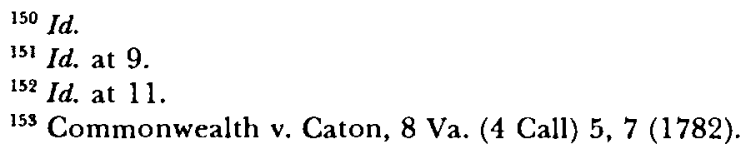


intent meaning subjective intent. The "honourable member of the G.C." ${ }^{154}$ presumably referred to one of the members of the General Convention that had framed the Virginia Constitution. ${ }^{155}$ This individual had some inside knowledge into why the constitution's pardoning clause was written as it was: "[I]t was the Intention of the Constitution to have as few Obstacles as possible in the way to mercy .... 156 Randolph derived intention by analyzing the document. Tucker, in contrast, is "informed" of it. He himself is not "competent to decide" the question of constitutionality. And by telling the court that he had been informed of the intent of the constitution, Tucker indicated that he believed the framers' subjective intent was relevant to judicial exegesis of the constitution, even though that intent was not apparent from the face of the constitutional document.

Tucker argued that the Treason Act could not survive scrutiny by a court that understood the constitution's meaning. "[The statute] not only gives powers where the Constitution had tacitly denied them, but renders that [the pardoning power of the House of Delegates] incompleat and inadequate which the Constitution had declared fully sufficient." 157 Again, it is striking that Tucker's determination that the statute was unconstitutional is not based on an express conflict between statute and constitution; the statute is unconstitutional because it allocates a power to the Senate which the constitution had, as Tucker put it, "tacitly" denied. Tucker's conclusion made clear that he believed that his earlier statement that a statute had to be "irreconcilably" at odds with the constitution to be unconstitutional was consistent with the position that this statute was unconstitutional. "Here then I apprehend," Tucker stated, "we may trace an absolute Contradiction-For the Law declared that to be insufficient which the Constitution had before

${ }^{154}$ See supra text accompanying note 152.

${ }^{155}$ For another example of such a reference to the 1776 convention, see RALPH KETCHAM, JAMES MADISON: A BIOGRAPHY 68 (1971) (referring to the May 1776 meeting of Virginia delegates at Williamsburg as the "General Convention"). Similarly, contemporaneous references to the Federal Constitutional Convention as the "General Convention" were standard. See, e.g., 3 THE RECords OF THE. FEDERAL CONVENTION OF 1787, supra note 14, at 545 (James Madison); 4 id. at 83 (same); 2 ANNALS OF CONG. 1360 (1790) (statement of Eldridge Gerry). Alternatively, "G.C." could, theoretically, have been an abbreviation for "Governor's Council" or "General Court," but since Tucker was referring to someone with special knowledge of the "Intention of the Constitution," it seems clear "G.C." denoted "General Convention."

${ }^{156}$ See supra text accompanying note 152.

${ }^{157}$ Tucker, supra note 8 , at 12 . 
declared to be fully sufficient, competent and compleat."158 In other words, there could be an "absolute Contradiction" between a statute and the constitution even when the statute did not run afoul of an express constitutional prohibition, but rather the "spirit" of the constitution. The Treason Act was unconstitutional even though the constitution did not explicitly bar the Senate from sharing in the pardoning power. It was unconstitutional because the framers had wanted pardoning to be easy.

\section{H. The Decision of the Virginia Court of Appeals}

On November 2, 1782, Randolph wrote Madison:

The great constitutional question, which was mentioned in my last letter, as having been adjourned from the general court to the court of appeals, received a second solemn hearing on thursday. The Judges, impressed with the dignity of it, have taken time until this day, when it will be finally decided, if some collateral objections should not prevent the dicision [sic]. ${ }^{159}$

When the court reconvened later that day, the eight judges delivered eight separate opinions, ${ }^{160}$ and the three prisoners lost in their bid for freedom. ${ }^{161}$ The rationale behind the result, however, as well as the exact vote, is a matter of dispute.

Reporter Daniel Call records all eight judges as ruling against the prisoners. ${ }^{162}$ According to Call, Chancellor Pendleton, adopting Randolph's statutory interpretation argument, concluded that the Treason Act was consistent with the constitution and reserved the issue whether a court could pronounce a statute invalid. ${ }^{163}$ The other seven judges each declared that the court could pronounce a statute unconstitutional and void but, like Pendleton, accepted Randolph's statutory argument and decided that the statute was constitutional. ${ }^{164}$ Thus, although the prisoners lost,

${ }^{158} I d$.

${ }^{159}$ Letter from Edmund Randolph to James Madison (Nov. 2, 1782), in 5 MADISON PAPERS, supra note 8, at 230, 230.

${ }^{160}$ See 2 MAYS, supra note 6 , at 196 (noting that each judge was ordered to prepare his own opinion); see also Pendleton, supra note 6, at 426-27 (summarizing the judges' opinions).

${ }^{161}$ See Commonwealth v. Caton, 8 Va. (4 Call) 5, 20 (1782).

${ }^{162}$ See id. at 13, 20.

${ }^{163}$ See id. at 17-18.

${ }^{164}$ See id. at 20. 
seven of the eight judges concluded that they had the power to overturn statutes, and the final judge did not reach the issue. ${ }^{165}$

Chancellor Pendleton's notes reflect a more complicated range of views. ${ }^{166}$ They indicate that two of the eight judges ruled in favor of the prisoners. Justice James Mercer found that the court had jurisdiction in criminal cases, stated that the Treason Act was unconstitutional, and concluded that the pardon was therefore good. ${ }^{167}$ Justice Bartholomew Dandridge did not reach the issue of the legitimacy of judicial review and he said he was "doubtful" as to whether the court had jurisdiction. ${ }^{168} \mathrm{He}$ stated that the statute and the constitution set up alternate means to pardon, the former by requiring the approval of both houses of the General Assembly, the latter requiring the approval only of the House of Delegates. The pardon of the three prisoners was a valid pardon under the constitution. ${ }^{169}$

Of the six judges who ruled against the prisoners, all upheld the Treason Act as constitutional. Only Justice Peter Lyons rejected judicial review; he was "[a]gainst the Power of the Court to declare an Act of the Legislature void." 170 Lyons, however, also concluded that the act was not "against the Constitution." ${ }^{n 171}$ At the other end of the spectrum on the matter of judicial review, Chancellor Wythe "[u]rged several strong and sensible reasons of the nature of those used by Lord Abblington, to prove that an Anti-constitutional Act of the Legislature would be void; and if so, that this Court must in Judgment declare it so, or not decide according to the Law of the land." 172 He found, however, that the Treason Act was constitutional and that the pardon by the House of Delegates was therefore invalid. ${ }^{173}$

According to Pendleton's notes, no judge other than Wythe and Mercer pronounced himself in favor of judicial review. Pendleton came the closest, reserving the issue but suggesting that a court had

${ }^{165}$ See id. at 7-21.

${ }^{166}$ See Pendleton, supra note 6 , at $426-27$ (summarizing the respective views of each judge).

${ }^{167}$ See id.

${ }^{168}$ Id. at 426.

${ }^{169}$ See id. at $426-27$.

${ }^{170} \mathrm{Id}$. at 426.

${ }^{171} I d$. at 427 . Justice Lyons was also the only judge of the six to find that the court did not have jurisdiction. See id. at 426.

${ }^{172}$ Id.

${ }^{173}$ See id. 
the power to pronounce a statute unconstitutional. ${ }^{174}$ Chancellor Blair and Justice Dandridge reserved the issue of whether a court had power to declare a statute unconstitutional without offering a hint as to how they would resolve the question if forced to do so. ${ }^{175}$ Judge Cary and Chief Justice Carrington resolved the issue of constitutionality without mentioning the question of judicial review. ${ }^{176}$ Even if one believes, as Professor Julius Goebel apparently did in his analysis of the opinions, that the fact that Carrington and Cary analyzed the statute and pronounced it constitutional suggests that they believed that courts had the power to review statutes for constitutionality, the Case of the Prisoners is still not a precedent for judicial review. ${ }^{177}$ Only four of the eight judges would have supported judicial review (and only actually voted to invalidate the statute). Moreover, Randolph's November 8, 1782 letter to Madison shows that he viewed the court as having left open the question of the legitimacy of judicial review. ${ }^{178}$

Pendleton's notes report only his opinion in any detail. " $[\mathrm{M}] \mathrm{y}$ memory," he wrote, "will not allow me to do Justice to the reasoning of the other Judges," 179 and therefore he only recorded the results they reached. Pendleton's account is presumably more accurate than Call's, since it was contemporaneous. At the same time, it is not the case, as Crosskey suggests, ${ }^{180}$ that Call was simply working from Pendleton's notes and altering them in order to strengthen his claim that Commonwealth v. Caton (as the reporter called it)

was the first case in the United States, where the question relative to the nullity of an unconstitutional law was ever discussed before judicial tribunal [and which] ... fixed a precedent, whereon, a

${ }^{174}$ See id. at 422.

${ }^{175}$ See id. at 426 .

${ }^{176}$ See id.

${ }^{177}$ Using Pendleton's notes, Julius Goebel, Jr., concluded that the Case of the Prisoners was a precedent for judicial review, stating, "Five decided explicitly or by inference that the Court of Appeals had the power to declare a law void for unconstitutionality." 1 GOEBEL, supra note 4, at 127. Goebel classified Lyons as denying this to be the case, and Dandridge and Blair as declining the question. See id. This leaves Cary, Carrington, and Pendleton as those in favor of judicial review. As will be discussed, however, Pendleton's notes indicate that he reserved the issue. See infra text accompanying notes 192-99.

${ }^{178}$ Letter from Edmund Randolph to James Madison (Nov. 8, 1782), in 5 MADISON PAPERS, supra note 8 , at 262,263 ("The judges of the court of appeals avoided a determination, whether a law, opposing the constitution, may be declared void, in their decision of Saturday last.").

${ }^{179}$ Pendleton, supra note 6 , at 418 .

${ }^{180}$ See 2 CrosskeY, supra note 1, at 952, 960 (questioning Call's report). 
general practice, which the people of this country think essential to their rights and liberty, has been established. ${ }^{181}$

If Call had been working from Pendleton's notes, he presumably would have included all of the language in Pendleton's notes indicating that he was sympathetic to judicial review. Call did not do this. ${ }^{182}$ It appears, instead, that Call was working from some other set or sets of notes of the court's opinions-perhaps a set of St. George Tucker's, since Call dedicated the volume containing this case to Tucker and acknowledged "the assistance [Tucker] kindly lent me, to complete the following work." ${ }^{183}$ Thus, where Call's account is consistent with, but more detailed than, Pendleton's-as is the case with his report of Wythe's opinion-Call's report is presumably accurate.

The only two opinions for which either account offers any detail are Wythe's and Pendleton's. As previously noted, Pendleton's brief account of Wythe's ruling makes clear that Wythe adopted the position that an "Anti-constitutional Act of the Legislature would be void; and if so, that this Court must in Judgment declare it so." 184 Call's report elaborates on Wythe's rationale. The argument for judicial review advanced by Wythe (as reported by Call) is a separation of powers argument. The judiciary is the neutral arbiter enforcing the boundaries established by the community through the constitution. The discussion below follows Call's more detailed account of Wythe's opinion.

At the start of his opinion, Wythe stressed the importance of "discussions upon the respective rights of the sovereign and the subject; and, upon the powers which the different branches of government may exercise. For, by this means, tyranny has been

${ }^{181} 8$ Va. (4 Call) at 20-21.

${ }^{182}$ See, e.g., Pendleton, supra note 6, at 422 ("Like all other declared Powers each [branch of government] has its limits, the Legislative as well as the others, which if they Pass, it would seem their Act would be void, as well as that of an Attorney would be, which was not Warranted by his appointment."). There is no similarly strong language about a statute apparently being "void" in Call's report.

${ }_{183} 8 \mathrm{Va}$. (4 Call) at v. If, however, Call worked from Tucker's notes of the decision, they do not appear to have been preserved. The file of Tucker's papers on the Case of the Prisoners at the Earl Gregg Swem Library is limited to his notes of his argument.

In addition, Call apparently did not use Tucker's notes of his own argument. Call did not, in any case, mention what that argument was or, indeed, that Tucker had argued. Call merely observed that the prisoners' counsel "and several other distinguished gentlemen" argued on their behalf. Id. at 6 .

${ }^{184}$ Pendleton, supra note 6 , at 426; see supra note 172. 
sapped, the departments kept him within their own spheres, the citizens protected, and general liberty promoted. ${ }^{n 185}$ He then celebrated judicial review as fulfilling the ends pursued by those discussions:

[T]his beneficial result attains to higher perfection, when those, who hold the purse and the sword, differing as to the powers which each may exercise, the tribunals, who hold neither, are called upon to declare the law impartially between them. For thus the pretensions of each party are fairly examined, their respective powers ascertained, and the boundaries of authority peaceably established. ${ }^{186}$

In the critical paragraph of the opinion's treatment of judicial review, Wythe makes clear both that the issue in the case is whether the legislature has exceeded its constitutionally delegated powers and that the purpose of judicial review is to hold the other branches of government in check:

I have heard of an english chancellor who said, and it was nobly said, that it was his duty to protect the rights of the subject, against the encroachments of the crown; and that he would do it, at every hazard. But if it was his duty to protect a solitary individual against the rapacity of the sovereign, surely, it is equally mine, to protect one branch of the legislature, and, consequently, the whole community, against the usurpations of the other: and, whenever the proper occasion occurs, I shall feel the duty; and, fearlessly, perform it. Whenever traitors shall be fairly convicted, by the verdict of their peers, before the competent tribunal, if one branch of the legislature, without the concurrence of the other, shall attempt to rescue the offenders from the sentence of the law, I sliall not hesitate, sitting in this place, to say, to the general court, Fiat justitia, ruat coelum; and, to the usurping branch of the legislature, you attempt worse than a vain thing; for, al though, you cannot succeed, you set an example, which may convulse society to its centre. Nay more if the whole legislature, an event to be deprecated, should attempt to overleap the bounds, prescribed to them by the people, $I$, in administering the public justice of the country, will meet the united powers, at my seat in this tribunal; and, pointing to the constitution, will say, to them, here is the limit of your authority; and, hither, shall you go, but no further. ${ }^{187}$

${ }^{185}$ Commonwealth v. Caton, 8 Va. (4 Call) 5,7 (1782).

${ }^{186} \mathrm{Id}$. at 8.

${ }^{187}$ Id. at 13 . 
The way in which the argument is cast is illuminating. The hypothetical horrible envisioned by Wythe is not that one branch of the legislature is causing the execution of prisoners who are constitutionally entitled to their lives and freedom. Rather, it is that one branch of the legislature is "attempting to rescue the offenders from the sentence of the law." This underscores the fact that, for Wythe, this case was about separation of powers; it was not about any right that the prisoners might have had under the pardoning clause of the state constitution.

Having announced his commitment to judicial review, Wythe then pronounced the statute constitutional, adopting the alternative readings of the constitution that Randolph had proposed (and had suggested to Madison were strained). ${ }^{188}$ "This mode of considering the subject, obviates the objection made by the prisoners' counsel, relative to the constitutionality of the law concerning treason," he concluded, "for, according to the interpretation just discussed, there is nothing unconstitutional in it." 189

Wythe's opinion, as reported by Call, implicitly advances a notion of judicial review in which legislative acts are void if they are inconsistent with a constitutional text. It should be added, however, that Pendleton's very brief account leaves open another possibility. The reference to "Lord Abblington" is suggestive. ${ }^{190}$ Lord Abingdon's 1777 Thoughts on the Letter of Edmund Burke to the Sheriffs of Bristol on Affairs in America argued that no duty of obedience existed to laws inconsistent with the constitution. ${ }^{191}$ Thus, there is at least a possibility that the actual opinion delivered by Wythe reflected a notion of judicial review that was based on the older, English-based notion of constitutionality, rather than on a notion of a constitution as written law. Under the older view, the citizen had no obligation to obey the unconstitutional statute because that statute violated the compact between governed and governors; disobedience was justified, but it was also tantamount to an act of rebellion. In contrast, the modern notion of a constitution as written law sees the declaration of a statute as unconstitutional as occurring within the context of normal governance: when a court finds a statute

\footnotetext{
${ }^{188}$ See id.

189 Id.

${ }^{190}$ See Pendleton, supra note 6 , at 426 .

${ }^{191}$ See 1 GOEBEL, supra note 4, at 127-28 (suggesting that the reference was to Abingdon's work).
} 
unconstitutional, it is simply choosing which of two laws to apply, the statute or the constitution.

Chancellor Pendleton's opinion, as reflected in his notes, embodies the premises supporting judicial review, but it stops short of embracing judicial review. Pendleton begins the section of his opinion concerned with judicial review by observing that "very little light has been thrown upon the Subject, by researches into the history of other Countreys. ${ }^{192}$ Even British precedent was useless:

We find the same author Lord Coke asserting at one time the omnipotence of Parliament, who may even change the Consti[tu]tion, and another exalting the Judiciary above them, giving Courts power of declaring Acts of Parliament void because they are impertinent or contrary to right and Reason, both of which are mere speculative opinions and neither of them worthy of adoption by the Legislature or Judiciary. ${ }^{193}$

Virginia's written constitution made the controversy about a statute's constitutionality different from any European precedent:

We however have happily in our hands the certain record of our Constitution containing the Original Social Compact, wherein the people have made their Government to consist of three great branches, the Legislative, Executive and Judiciary, allotting to each, its proper powers, and declaring that they shall be kept separate and distinct, neither exercising those which belong to another. Like all other declared Powers each has its limits, the Legislative as well as the others, which if they Pass, it would seem their Act would be void, as well as that of an Attorney would be, which was not Warranted by his appointment. ${ }^{194}$

This relatively brief passage strings together a number of critical points. The constitution is the original social compact. As Pendleton's use of words such as "allotting" and "declaring" indicates, he did not see the constitution as simply codifying preexisting power relations; it created power relations. The legislature was not, as it was in Blackstonian thought, supreme: its power was limited and its acts, "it would seem," could be "void." 195 The theory justifying those limits was a delegation theory: the people,

\footnotetext{
192 Pendleton, supra note 6 , at 422.

${ }^{199}$ Id. (alteration in original).

194 Id.

${ }^{195} I d$.
} 
through the constitution, vested only certain powers in the legislature and nothing more.

The quoted text suggests that Pendleton was in favor of judicial review. The ideas that a branch of government had been delegated only limited powers, that a written constitution made those limits ascertainable, and that a legislative act exceeding the legislature's powers would be "void" became the critical elements in the judicial review theories of Iredell, Hamilton, Wilson, and Marshall ${ }^{196}$ (and, as we have seen, they were the critical elements in Tucker's and Randolph's approaches as well). During the Stamp Act crisis, as a justice in Caroline County, he had taken the position that the Stamp Act was inconsistent with the British Constitution and that the court should disregard it. ${ }^{197}$ Moreover, in 1788, Pendleton would write an opinion for the court of appeals declaring that when "the constitution and the act are in opposition and cannot exist together[,] . . the former must control the operation of the latter." 198 In 1782, however, he refrained from reaching this conclusion and suggested that it was an open question whether at some point the judicial power to invalidate legislation arguably became a legislative power and hence unconstitutional:

But how far this Court in which it has been properly said the Judiciary Powers of the State are concentrated, can go in declaring an Act of the Legislature void, because it is repugnant to the Constitution, without exercising the Power of Legislation, from which they are restrained by the same Constitution? is a deep, important, and, I will add, an awful question; from which, however, I will not shrink, if ever it shall become my duty to decide it: at present $\mathrm{I}$ am happy in having no occasion to make the decision .... ${ }^{199}$

Pendleton was able to avoid resolving the question whether a court had the power to invalidate statutes by deciding that the Treason Act was not in conflict with the constitution. He noted that he had been Speaker of the House at the time the statute was passed and that its constitutionality had been "[w]armly" debated

${ }^{196}$ See supra notes 91-94 and accompanying text (noting the judicial review theories of Iredell, Hamilton, Wilson, and Marshall).

${ }^{197}$ See 2 MAYs, supra note 6, at 168-71.

${ }^{198}$ Cases of the Judges of the Court of Appeals, 8 Va. (4 Call) 135, 142 (1788). For a discussion of these cases, see infra text accompanying notes 322-26. See also 2 MAYs, supra note 6, at 199 (ascribing authorship of the principal opinion to Pendleton).

${ }^{199}$ Pendleton, supra note 6 , at 422. 
then. ${ }^{200}$ He added that, as the presiding official, he had been unable to debate, but had decided that the statute was constitutional then and that "I have found no reason to alter [that opinion]." 201

The question of what the constitution meant turned on whether "the power of pardoning is reserved to ... one or both houses [of the legislature]." ${ }^{202}$ This question, he declared, "should be decided according to the spirit, and not by the words of the constitution. ${ }^{203}$ Pendleton noted Randolph's suggestion

of throwing the words "or the laws shall otherwise particularly direct," into a Parenthesis, leaving the latter words to operate upon the cases of Prosecutions by the House of Delegates only, and the Legislature with full power to direct the mode of Pardon in other cases, in which they restrain the Executive. ${ }^{204}$

He rejected this interpretation, however, because "it does not reach my Idea of the Spirit of the constitution" ${ }^{205}$ because it would permit the legislature to give the Senate exclusive power to pardon in all cases except those involving impeachments by the House of Delegates, thus dramatically diminishing the House of Delegates's role in pardoning. ${ }^{206}$ Pendleton, however, adopted Randolph's other suggested reading. The constitutional language that nongubernatorial pardons could not be granted "but by resolve of the House of the Delegates ${ }^{207}$ meant, according to Pendleton, that such pardons could not be granted "without the Consent,' of the House of Delegates." ${ }^{208}$ Thus, the legislature could pass a statute that, in cases in which the Executive did not have the power to pardon, approval by the House of Delegates would be a necessary, but not sufficient, condition for a pardon.

Approval by both legislative houses would thus be necessary for an effective pardon. Such a reading was "congenial to the spirit, and not inconsistent with the letter, of the constitution." 209 The Treason Act, because it was consistent with this reading of the

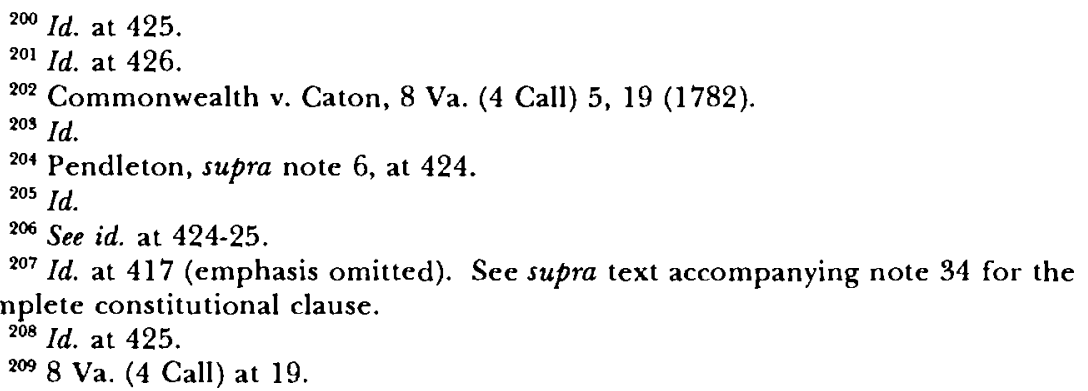


constitution, was constitutional. Like Wythe, therefore, Pendleton read the constitution in a way that Randolph had proposed to the court but that Randolph had privately suggested, "to any but lawyers[,] ... would appear unintelligible." ${ }^{\text {210 }}$ Like the others, Pendleton was evidently attempting to avoid a holding that the constitution and the statute were at odds. At the same time, he did not make this interpretative approach explicit: he did not state that the constitution should be interpreted in a way that avoided a determination that a statute was inconsistent with it.

Six days after the decision, Pendleton wrote Madison:

The great Constitutional question, as it was called in our papers ... was determined in the Court of Appeals by 6 Judges against two, that the Treason Act was not at Variance with the Constitu[tion] but a proper exercise of the Power reserved to the Legislature by the latter, of directg. in what other cases besides that of Impeachments by the House of Delegates, the Executive should be restrain'd from Pardoning, including in it the power of directg the mode of Pardon in all such Cases, provided such mode should necessarily involve the Consent of the House of Delegates which it was thought preserved the Spirit of the Constitution \& was the best Interpretation wch [sic] the Inaccurate words of the Constitution would admit of ....211

Thus, Pendleton acknowledged the constitution's ambiguity-its "Inaccurate words"-but the way in which the constitution had been construed pleased him. "[T]he Spirit of the Constitution" had been preserved.

\section{Aftermath}

The fact that two judges had explicitly embraced judicial review-perhaps the first judges to do $\mathrm{so}^{212}$-and the fact that the

${ }^{210}$ Letter from Edmund Randolph to James Madison (Nov. 8, 1782), in 5 MADISON PAPERS, supra note 8, at 262, 263; see also supra note 101 and accompanying text (noting Randolph's admission that his readings of the constitution were strained).

${ }^{211}$ Letter from Edmund Pendleton to James Madison (Nov. 8, 1782), in 5 MADISON PAPERS, supra note 8, at 260, 261.

${ }^{212}$ The Case of the Prisoners is chronologically the third of the nine cases that have been advanced as possible revolutionary-era judicial review cases. See supra note 1. The weight of evidence indicates that, in fact, neither of the two earlier cases concerned the issue of judicial invalidation of legislation. In the oldest case-the Josiah Philips Case-Virginia Attorney General Randolph decided not to proceed against Philips on a bill of attainder, limiting the prosecution to other grounds. There was, however, no judicial determination that the bill of attainder was unconstitutional. See 2 CROSSKEY, supra note I, at 944-45. In Holmes $v$. Walton, the 
State's Attorney General had adopted the same position did not cause controversy. "[T]he Case of the Prisoners," Pendleton informed Madison in December, "was reduced to a thin[g] of small moment, by the opinion of the Court that the Treason law was not contrary to the constitution. ${ }^{213}$

Although the court of appeals had concluded that the Treason Act was constitutional, the House of Delegates, taking a more rigorous view of the matter, disagreed. On November 19, 1782, it passed a resolution stating "[t]hat so much of the Act of the General Assembly, declaring 'what shall be treason,' as vests the power of pardon for such offences in the General Assembly is unconstitutional, and ought to be amended. ${ }^{214}$ On November 23, 1782, the House followed up on its resolution and voted in favor of an act revising the Treason Act by vesting the power to pardon in the House of Delegates alone. ${ }^{215}$ In its preamble, the act asserted "the bounden duty of the representatives of the People at all times to preserve the constitution inviolate. ${ }^{216}$ Since the revised Treason Act was not enacted, however, the Senate presumably did not approve the bill, which suggests that the Senate believed that the existing Treason Act was constitutional.

What is of critical importance is the fact that the Case of the Prisoners, unlike other revolutionary-era decisions in which judges suggested that they had the power to review statutes or refused to hold that they did not have that power, did not provoke a negative response. There is no record of popular criticism of the two judges who asserted that the judiciary had the power to invalidate statutes. There was no move in the Senate against them. Moreover, the

only other case preceding the Case of the Prisoners, according to Professor Levy, "The constitutionality of the act was not at issue, and the court gave no opinion, not even in obiter dicta, on whether it had the power to void an act for unconstitutionality." LEVY, supra note 4, at 93 . If this is accurate, the decisions of Wythe and Mercer in the Case of the Prisoners would be the first postindependence judicial assertions of the power to invalidate statutes.

${ }^{213}$ Letter from Edmund Pendleton to James Madison (Dec. 9, 1782), in 5 MADISON PAPERS, supra note 8 , at $382,382$.

${ }^{214}$ JOURNAL OF THE HOUSE OF DELEGATES OF THE COMMONWEALTH OF VIRGINIA; Begun and Held in the City of Richmond, in the COUNTY of HenRico, ON MONDAY, THE TWENTY-FIRST DAY OF OCTOBER, IN THE YEAR OF OUR LORD ONE THOUSAND SEVEN HuNdRED AND EIGHTY-Two 24 (Nov. 19, 1782) (1828) [hereinafter JOURNAL OF THE HOUSE OF DELEGATES].

${ }^{215}$ See id. at 33 (Nov. 23, 1782).

${ }^{216}$ Hutchinson \& Rachal, Notes to Letter from Edmund Randolph to James Madison (Oct. 26, 1782), in 5 MADISON PAPERS, supra note 8, at 217, 219 n.10 (quoting preamble). 
Senate joined the House in providing the three prisoners the relief that they had sought from the outset. On November 15, facing execution, the prisoners renewed their request for legislative pardons. ${ }^{217}$ This time both houses concurred. All were pardoned subject to satisfaction of a condition. Lamb and Hopkins were required to leave the state and Caton was required to serve in the revolutionary army for the remainder of the war. ${ }^{218}$ "[T]his method of recruiting has been used with several other Criminals," Pendleton wrote Madison, "and if they prove good Soldiers, they will make the state abundant amends for former offences." ${ }^{219}$

\section{The Significance of the CASE OF THE PRISONERS}

This section will explore the ways in which the case study presented in the previous section bear on a number of major questions concerning the development of judicial review and early conceptions of constitutional interpretation. Contrary to the work of Professor H. Jefferson Powell, ${ }^{220}$ statements by participants in the Case of the Prisoners reveal the presence of a powerful antiliteralist approach to constitutional interpretation, one that looked beyond the text to the constitution's spirit and, in the case of Tucker, to evidence of the Framers' subjective original intent. Moreover, while leading modern accounts stress the constrained quality of early judicial review, both Tucker's argument and subsequent Virginia case law reflect an aggressive judicial stance.

Finally, the case and its aftermath illuminate Marbury: if one views Chief Justice Marshall as the product of a Virginia legal and political culture which accepted judicial review early and relatively easily, his assertion in Marbury of the power to review congressional legislation becomes understandable in a way that is wholly different from the classic debates about Marbury. Traditionally, the debate about Marbury has turned on whether judicial review was part of the original understanding or whether Marshall's decision reflected his desire to see that a Federalist judiciary had the power to check the Republican executive and legislature. This section contends that it

${ }^{217}$ See JOURNAL OF THE HOUSE OF DELEGATES, supra note 214, at 18-19 (Nov. 15, 1782).

${ }^{218}$ See id. at 58 (Dec. 4, 1782); Letter from Edmund Pendleton to James Madison (Dec. 9, 1782), in 5 MAdison PAPERS, supra note 8, at 382, 382.

${ }^{219}$ Letter from Edmund Pendleton to James Madison (Dec. 9, 1782), in 5 MADISON PAPERS, supra note 8 , at $382,382$.

${ }^{220}$ See Powell, supra note 13. 
was natural for a jurist produced by the Virginia political and legal culture to champion judicial review, regardless of his politics and regardless of whether judicial review was a consensus part of the original understanding of the constitution.

\section{A. Constitutional Interpretation}

\section{Powell and Textualism}

In his influential article The Original Understanding of Original Intent, Professor Powell has argued that the Framers, members of the state ratifying conventions, and early interpreters of the Constitution believed that the subjective intent of the Framers was irrelevant to constitutional interpretation. ${ }^{221}$ Central to Powell's thesis is his analysis of the hermeneutical traditions that could have influenced the Framers. "Of the numerous hermeneutical options that were available in the framers' day," Powell writes, "none corresponds to the modern notion of intentionalism." ${ }^{222}$ In other words, none supported consideration of the Framer's subjective intentions in constitutional exegesis.

Powell contends that "[ $t]$ he two most obvious sources of hermeneutical wisdom [on which American constitutional interpreters could draw] were the anti-interpretive tradition of AngloAmerican Protestantism and the accumulated interpretive techniques of the common law." 223 The former tradition was Protestantism's "chaste literalism" which considered invalid "any exposition of the text that went beyond the text [itself]." ${ }^{224}$ This view repre-

${ }^{221}$ Powell, supra note 13. Powell's thesis has sparked substantial scholarly debate, although it has been fought largely on the terms of Powell's original article. In other words, participants in this controversy have parsed the debates in the Constitutional Convention, during the ratification controversy, and during the first years of the Republic for evidence of how the founding generation thought the Constitution should be construed. The two principal critics of Powell are Charles Lofgren and Raoul Berger. For Lofgren's critique, see generally Lofgren, supra note 13 . For the debate between Powell and Berger, see Raoul Berger, The Founders' Views-According to Jefferson Powell, 67 TEx. L. REv. 1033, 1033-34 (1989); Raoul Berger, "Original Inlention" in Historical Perspective, 54 GEO. WASH. L. REV. $296(198 \rightarrow \mathrm{H}$. Jefferson Powell, The Modern Misunderstanding of Original Intent, 54 U. CHI. L. REV. 1513 (1987) (reviewing RAOUL BERGER, FEDERALISM: THE FOUNDERS' DESIGN (1987)). This Article departs from the earlier work by focusing on a case; this focus is particularly appropriate because that case-the Case of the Prisoners-contains relatively explicit discussions of how a constitution should be interpreted.

${ }^{222}$ Powell, supra note 13 , at 948.

${ }^{223}$ Id. at 889.

${ }^{224}$ Id. at $889-90$. 
sented a rejection of Roman Catholicism's "tradition of interpretation, according to which literal exposition of the text was only one (and by no means necessarily the most important) methodology." ${ }^{225}$ Enlightenment thought reinforced this view. "The philosophes ... perceived traditional interpretation of Scripture as one of the chief props supporting the theological absurdities and religious oppression perpetrated by the established churches, and saw the niggling interpretation of complicated or obscure laws as a relic of feudal misrule and political tyranny." "226 "Such cultural reluctance to admit the legitimacy of significant interpretation of written documents strongly influenced Americans in their conceptualization of the task of interpreting their new Constitution. ${ }^{\text {227 }}$ The second tradition was the common-law tradition:

The modern practice of interpreting a law by reference to its legislative history was almost wholly nonexistent, and English judges professed themselves bound to honor the true import of the "express words" of Parliament ... . Political and legal scholars in both Britain and the American colonies viewed strict judicial adherence to the legislature's language as a constitutional necessity $\ldots .{ }^{228}$

According to Powell, an exception to this rule "occurred when the statute's wording was ambiguous, rather than clear but in conflict with its apparent intent." ${ }^{229}$ In this context, courts could look to evidence outside of the statute's text, but the search was highly constrained. They could consider the preamble of the statute, which Powell notes was not considered an "operative provision" of the statute. ${ }^{230}$ They could also consider prior usage under the statute. ${ }^{231}$ The critical interpretive guide was previous judicial construction: "judicial precedent served as the most

225 Id. at 889 .

${ }^{226} \mathrm{Id}$. at 892.

${ }^{227} \mathrm{Id}$. at $893-94$.

${ }^{228} \mathrm{Id}$. at $897-98$.

${ }^{229} \mathrm{Id}$. at 898 . Powell also discusses another exception to the rule that courts should not look beyond a statute's text: "where the text was defective on its face." Id. "In such situations," he writes, "judges were free to substitute coherence for gibberish." Id. Outside of the statutory context, Powell notes that courts construing wills "purport[ed] to pay particular attention to the subjective intentions of their drafters," but this concern was "largely illusory." Id. at 896.

${ }^{230}$ Id. at 899.

${ }^{231}$ See id. 
important source of information about an act's meaning beyond its actual text." 232 "This followed almost by definition from the basic notion of 'intent' as a product of the interpretive process rather than something locked into the text by its author. ${ }^{233}$

But even in such cases of statutory ambiguity the legislators' subjective intent was still not a source courts could consult. "It was generally agreed that such ambiguitas patens could not be resolved by extrinsic evidence as to Parliament's purpose. ${ }^{\text {234 }}$ Although references were made to "intent," the word was a term of art, signifying "not ... what the drafters meant by their words but rather ... what judges, employing the 'artificial reason and judgement of the law,' understood 'the reasonable and legal meaning' of those words to be." 235

Aware of both the religious tradition's and the common law tradition's relevance to constitutional interpretation, the drafters of the Constitution believed the latter would prove dominant:

The Philadelphia framers' primary expectation regarding constitutional interpretation was that the Constitution, like any other legal document, would be interpreted in accord with its express language .... The framers shared the traditional common law view-so foreign to much hermeneutical thought in more recent years-that the import of the document they were framing would be determined by reference to the intrinsic meaning of its words or through the usual judicial process of case-by-case interpretation. ${ }^{236}$

Early debates about the Constitution's meaning also reflected the influence of the two traditions. During the struggle for ratification, "Federalists ... treated the availability of common law hermeneutics as a positive good: precisely because there was a developed tradition of legal interpretation, they argued, the people could predict with confidence the results of future constitutional construction." ${ }^{237}$ In the political battles of the 1790 s over the Constitution, the members of the Federalist party relied on the common law interpretive model. "The Republicans, in contrast, took up the cudgels of the religious and philosophical opposition to

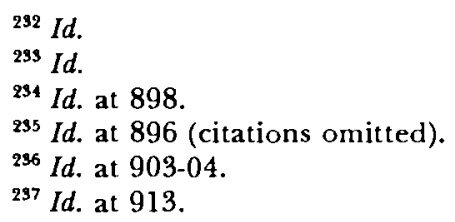


interpretation and warned that the 'wiles of construction' could be controlled only by a narrow reading of the Constitution's expansive language." 238

Significant appeals to original intent of any sort only began in 1798 with the Virginia and Kentucky Resolutions, written by Madison and Jefferson, respectively, as criticisms of the Alien and Sedition Acts. Jefferson and Madison "broke new ground" ${ }^{239}$ by invoking the official resolutions that various states had made when ratifying the Constitution as terms of the constitutional contract. " $[B] y$ focusing attention on a past historical event Jefferson and Madison raised the possibility that other historical documents might be relevant to determining the state's original intent." ${ }^{240}$ Even Madison, who became the principal theorist of this new "original intent" approach, did not, however, embrace anything like modern intentionalism. He never "regarded historical evidence of the framers' personal intentions as a definitive or even particularly valuable guide to constitutional construction. ${ }^{241}$

\section{The Case of the Prisoners, Original Intent, and Antiliteralism}

Powell's argument about the understanding that the Framers had when they wrote the Constitution and of how the Constitution would be interpreted is based on inference. As he acknowledges, "the Philadelphia framers did not discuss in detail how they intended their end product to be interpreted." 242 His claim that Protestant literalism and common-law hermeneutics were the principal influences on early thinking about constitutional interpretation thus does not reflect the fact that any contemporaneous commentator asserted that these were the appropriate guides. It largely reflects, instead, Powell's belief that these were the "two most obvious sources of hermeneutical wisdom. ${ }^{243}$

While he focuses on the English legal tradition, Powell does not discuss the American legal tradition-and specifically the judicial review cases of the revolutionary era. That he did not do so is understandable. Although scholars dispute precisely which of the

${ }^{238}$ Id. at 923 (citation omitted).

${ }^{239}$ Id. at 932 .

${ }^{240}$ Id. at 933 (emphasis omitted).

${ }^{241}$ Id. at 944 .

${ }^{242}$ Id. at 904 .

${ }^{243}$ Id. at 889. 
revolutionary-era cases invalidated statutes, it is clear that in these cases, courts either invalidated statutes principally for their failure to comply with some extraconstitutional source, such as natural law or tradition, or at least considered whether they could invalidate statutes on such grounds. Thus, they shed little light on what background notions concerning constitutional interpretation were available to the Framers. The Case of the Prisoners is the only revolutionary-era case in which we have a record of a court paying close attention to the interpretation of a written constitution. ${ }^{244}$

The previously known documents from attorneys who argued in these early cases also provide little illumination on constitutional interpretation. For example, the letters to the public of James Iredell, the attorney in Bayard $v$. Singleton, at the time of the Case of the Prisoners, concern his defense of judicial review as an institution, not the argument that he made in the case as to why the challenged statute was unconstitutional. ${ }^{245}$ Attorney James Varnum's argument in Trevett $v$. Weeden was principally based on natural law. ${ }^{246}$ Varnum was unable to invoke a popularly enacted state constitution for a very obvious reason: Rhode Island's Charter of 1663 remained in effect. ${ }^{247}$ Alexander Hamilton's argument in Rutgers $v$. Waddington concerned a claim that a New York statute violated the law of nations. ${ }^{248}$

Tucker's and Randolph's notes and other primary source material concerning the Case of the Prisoners are the best guides we have from the revolutionary era as to the Framers' view of constitutional interpretation. Admittedly, too much should not be read into documents from a single case. But, given the dearth of other information, the surviving material from the Case of the Prisoners becomes of critical significance. And evidence provided by the Case of the Prisoners suggests the prevalence of views of constitutional

244 See supra note 12 and accompanying text.

${ }^{245}$ See Iredell, supra note 91; see also Letter from James Iredell to Richard Spaight (Aug. 26, 1787), in 2 MCREE, supra note 91, at 172.

${ }^{246}$ See VARNum, supra note 1, at 11-17 (discussing the fundamental right to trial by jury).

${ }^{247}$ For the provisions of the Rhode Island Charter, see 5 THORPE, supra note 12 , at 3211 .

${ }^{248}$ See Brief No. 6 for Waddington, Rutgers v. Waddington (N.Y. City Mayor's Ct. 1784), reprinted in 1 GOEBEL, supra note 1 , at 362,368 . This argument is not developed; Hamilton simply made the point indicated in the text. See id. Hamilton's argument was indirectly a constitutional argument because the New York Constitution adopted the common law and, Hamilton asserted, the law of nations was a part of the common law. 
interpretation that are inconsistent with Powell's account. Specifically, analysis of the record of the case does not support Powell's view that the only interpretive traditions available to Americans were predominantly or exclusively textualist and that early interpretations of the Constitution were similarly textualist.

One example of the fact that participants in the case did not privilege text in the way that Powell's thesis would suggest is provided by Chancellor Pendleton's note to Madison after the case ended. Pendleton observed that the court's construction of the constitution was one "which it was thought preserved the Spirit of the Constitution [and] was the best Interpretation wch [sic] the Inaccurate words of the Constitution would admit of."249 This statement reflects the belief that the constitutional text was indeterminate and that constitutional "Spirit" was relevant to interpretation. His opinion in the case also reflects a concern with interpreting the constitution in accordance with its spirit. The question whether one or both Houses had the power to pardon "should be decided according to the spirit, and not by the words of the constitution. ${ }^{250}$ The chancellor rejected one of Randolph's readings of the constitution because "it does not reach my Idea of the Spirit of the constitution." 251 The reading that Pendleton embraced was "most congenial to the spirit, and not inconsistent with the letter, of the constitution. ${ }^{252}$

Randolph's and Tucker's notes provide more detailed evidence of a limited commitment to text as a source of meaning. At the core of their arguments were their invocations of the Virginia Constitution's spirit. Randolph contrasted construction of a constitution with construction of a statute. In the construction of a statute "the masculine force of substantial sense is too often subjected to the petty tyranny of grammatical rule, ${ }^{253}$ but with a constitution "the liberality, necessary to catch its spirit, must be adopted." 254 Thus, whereas Powell sees the common-law hermeneutic as establishing the very limited outer bounds for the use of nontextual sources, Randolph specifically rejects the common-law tradition because it is too text-bound-"subjected to the petty

${ }^{249}$ Letter from Edmund Pendleton to James Madison (Nov. 8, 1782), in 5 MADISON PAPERS, supra note 8, at 260, 261.

${ }^{250}$ Commonwealth v. Caton, 8 Va. (4 Call) 5, 19 (1782).

${ }^{251}$ Pendleton, supra note 6, at 424.

$2528 \mathrm{Va}$. (4 Call) at 19.

${ }^{253}$ Randolph, supra note 8 , at 3 .

${ }^{254}$ Id. 
tyranny of grammatical rule"-and therefore lacking the "liberality, necessary to catch [the constitution's] spirit." 255

In setting forth his vision of the constitution's spirit, Randolph appealed to framers' intent: “[E]very argument which tends to the propriety of uniting [the Senate] in pardoning in these instances [of impeachments], will prove the great improbability of their exclusion being intended in any other." ${ }^{256}$ As previously noted, Randolph did not ascertain intent by discussing evidence of the subjective intent of the framers. Nonetheless, as Randolph's explicit rejection of the common-law tradition indicates, his approach was still much less constrained by the text than the common-law tradition would have dictated. Rather than seeking relevant judicial precedent or resting his claims on traditional canons of construction, Randolph advanced an argument that was largely structural, highlighting the selection process for senators and constitutional limits on the Senate's power: selected by the people, rather than inheriting their office, unable to originate or amend money bills, senators were not "by their powers as much of aristocracy as would hang on an aspin [sic] leaf." 257 Moving even farther beyond the text, Randolph also reminded the court of who the senators were and that they were the same kind of people as those who sat in the House of Delegates: "[Treason] strikes as deep into the happiness of the Senate as citizens, and their existence as a body. Their judgment will be as keen, and irritation vs. the offense as acute [as the House of Delegates]." 258 In essence, Randolph was making the claim that the framers had no reason to deny the senators a role in the pardoning power because they would not be aristocrats and that the constitution should be interpreted accordingly. In Powell's account, structuralism and original intent enter American constitutional discourse with the Virginia and Kentucky Resolutions, and in both doctrines were used in a very limited fashion: "The intentionalism of the Resolutions was therefore a form of structural interpretation carried out by inference from the nature both of compacts and of sovereignty. It was the 'intent' of the states as political entities that the Resolutions deemed normative for purposes of constitutional interpretation. ${ }^{\text {259 }}$

\footnotetext{
${ }^{255} \mathrm{Id}$.

${ }^{256} I d$. at 4 (emphasis added).

${ }^{257}$ Id. at 5.

${ }^{258}$ Id. at 6.

${ }^{259}$ Powell, supra note 13 , at 931.
} 
In addition, Randolph took the position that in cases in which a statute was challenged, unless text and spirit were in direct opposition, the spirit of the constitution controlled constitutional interpretation, even over the text's apparent meaning. "For if [the constitution's] spirit opposes the exclusion of the Senate, its words must be free from ambiguity and decided, or cannot have the supremacy." 260 Randolph thus was shifting the burden with respect to the judicial obligation to follow the text. While in statutory construction "the masculine form of substantial sense is too often subjected to the petty tyranny of grammatical rule," in constitutional interpretation the spirit controls, unless the text is unambiguous. ${ }^{261}$ The extent to which Randolph believed spirit superior to plain textual meaning is indicated by his observation to Madison that "I doubt not, that to any but lawyers the construction, by which the two [statutory and constitutional provisions] were reconcile[d,] would appear unintelligible." ${ }^{262}$

Appeals to the spirit of the constitution are, if anything, even more central to Tucker's argument than to Randolph's. Tucker appeals to the spirit of the constitution to justify the institution of judicial review when he invokes Montesquieu for the view that "the same Man or body of Men should not enact Laws, or afterwards carry them into Execution" and adds that that view of limited powers "is also the Spirit of our Constitution." 263 He invokes it again as a basis for constitutional interpretation: "the Spirit of our Constitution declares that the power of pardoning in all Cases where it is not given to the Executive, is vested in the House of Delegates alone."264

As previously discussed, in locating spirit, Tucker specifically turned to the subjective intent of the framers: "I am informed by an honourable member of the G.C. that it was the Intention of the Constitution to have as few obstacles as possible in the way to mercy." ${ }^{265}$ Thus, Tucker's notes reflect an approach to constitutional interpretation consistent with modern original intent jurisprudence. In other words, Tucker's approach was opposite to that which Powell ascribes to the framers.

${ }^{260}$ Randolph, supra note 8 , at 6 .

261 Id. at 3 .

${ }^{262}$ Letter from Edmund Randolph to James Madison (Nov. 8, 1782), in 5 MADISON PAPERS, supra note 8, at 262, 263.

${ }^{263}$ Tucker, supra note 8 , at 4 .

${ }^{264} I d$. at 11 (emphasis omitted).

265 Id. 
It should be added that not everyone in the case stressed spirit. Andrew Ronald, the attorney for the prisoners, employed arguments that embody the hermeneutical approaches discussed by Powell. He attacked Randolph's use of original intent, saying "the words of the constitution, and not conjectures drawn from the supposed meaning of the framers of it, should give the rule." ${ }^{266}$ He appealed to text: "the act of assembly was contrary to the plain declaration of the constitution; and therefore void." ${ }^{267}$ He acknowledged that ambiguity was possible, but suggested a canon of construction as a way to resolve it: "the construction ought, in favour of life, to incline to the side of mercy. ${ }^{n 268}$

Thus, the Case of the Prisoners does not suggest that Powell's account is wrong. It does suggest that that account is incomplete. There were other interpretive approaches available to the Framers of the United States Constitution, and, if the Case of the Prisoners is representative, those approaches may have been dominant. In particular, both Tucker, by invoking the subjective intent of the framers of the Virginia Constitution, and Randolph, by rejecting the traditional approach of statutory interpretation, embraced interpretive stances at odds with those of Powell.

The appeals to the spirit of the Virginia Constitution made by Randolph, Tucker, and Pendleton accord, not with Powell's vision, but with Professor Morton Horwitz's novel claim in his 1993 Harvard Foreword, The Constitution of Change: Legal Fundamentality Without Fundamentalism, that "a distinct anti-literalism seems to have been present among some of the Virginia founders." 269 Horwitz invokes two examples in support of this thesis. The first is Madison, and specifically his statement in Federalist No. 37:

[H] owever accurately objects may be discriminated in themselves, and however accurately the discrimination may be considered, the definition of them may be rendered inaccurate by the inaccuracy of the terms in which it is delivered. And this unavoidable inaccuracy must be greater or less, according to the complexity and novelty of the objects.... ${ }^{270}$

${ }^{266}$ Commonwealth v. Caton, 8 Va. (4 Call) 5, 7 (1782).

${ }^{267}$ Id.

${ }^{268}$ Id.

${ }^{269}$ Horwitz, supra note 17 , at 49.

${ }^{270}$ The FEDERALIST No. 37, at 229 (James Madison) (Clinton Rossiter ed., 1961), quoted in Horwitz, supra note 17, at 50. 
The second example is Chief Justice Marshall and in particular his statement in $\mathrm{McCulloch}$ that the federal government could employ "means" that were "appropriate" to achieve "legitimate" ends, and that among the appropriate means were those that "consist with the letter and spirit of the constitution." ${ }^{271}$ Horwitz writes: "The distinction between the letter and spirit appears to have been a major source of anti-literalism during the nineteenth century." 272

The statements from the Case of the Prisoners that have been discussed reveal the same awareness evidenced in the examples cited by Horwitz of the limits of text and the appropriateness of looking beyond text to establish a rule of law. Thus, these statements provide support for Horwitz's thesis about antiliteralism and indicate that antiliteralism predated the framing of the Constitution. They also show that the antiliteralist approach could be employed not just to empower the national government (as Marshall used it), but also to invalidate statutes passed by a coequal branch of the same government (as Tucker urged).

Horwitz suggests that the antiliteralist approach drew on two hermeneutic traditions. First, it drew on a Protestant evangelical tradition that stressed the spirit of the law (to which all had access) over the letter (of which the learned clergy claimed a superior mastery). ${ }^{273}$ Second, it reflected the influence of eighteenth century Scottish Enlightenment thinkers such as David Hume, whose work stressed the multiplicity of meanings that particular language could yield. ${ }^{274}$ Both such influences are plausible. In particular, Scottish Enlightenment philosophy clearly influenced Tucker, who referred to Frances Hutcheson's Moral Philosophy in his law lectures. ${ }^{275}$ In addition to these two traditions, a third merits mention. A relatively lax form of Anglicanism was the dominant religion among the Virginia elite, ${ }^{276}$ and the Anglican tradition

${ }^{271}$ McCulloch v. Maryland, 17 U.S. (4 Wheat.) 316, 421 (1819), discussed in Horwitz, supra note 17 , at 50.

${ }^{272}$ Horwitz, supra note 17 , at 50-51.

${ }^{273}$ See id. at 50 n. 90 .

${ }^{274}$ See id. at 49 \& n. 86.

${ }^{275}$ See Cullen, supra note 8 , at 145 . On Scottish Enlightenment thought generally, see GARRY WILLS, INVENTING AMERICA $175-92(197 \rightarrow$ William Michael Treanor, Taking the Framers Seriously, 55 U. CHI. L. REv. 1016, 1028-31 (1988) (book review).

${ }^{276}$ See Sydney E. Ahlstrom, A Religious History of the American PeOple 188 92 (1972) (discussing the Anglican establishment in Virginia and noting that strict Anglicanism was not observed); see also RHYS ISAAC, THE TRANSFORMATION OF VIRGINIA, 1740-1790, at 278-93 (1982) (describing the unsuccessful attempt by the 
cautioned against acceptance of the biblical text as literally true. ${ }^{277}$ Thus, there were other hermeneutic traditions beyond those identified by Powell that were available to revolutionary Americans and that did not rely on text to the same degree as the interpretive traditions he identifies. The principal point here, however, is not to identify specific sources of influence, but to indicate that the Case of Prisoners fits into a larger tradition in late-eighteenth-century America of antiliteralism. That tradition is perhaps best summed up by one of Hamilton's briefs in Rutgers: "In law as in Religion THE LETTER KILLS The SPIRIT MAKES ALIVE." ${ }^{278}$ While Hamilton's specific concern in making this argument in Rutgers was with statutory interpretation, the Case of the Prisoners suggests that this extratextual focus had application to constitutional interpretation as well.

If one takes a nonliteral approach to text, then the question becomes what other sources to look to, beyond the text, in deriving meaning. Tucker invoked the Framer's subjective intent. Again, one can use the Case of the Prisoners as a starting point and fit this evidence into a larger framework. Contrary to Powell's thesis, from the start of the Republic, leading politicians appealed to Framers' intent as a way of resolving constitutional controversy. Thus, in 1791 , in the dispute over whether Congress had the power to charter a national bank, Jefferson argued that it did not, because the Framers had voted against giving Congress the power to charter corporations. ${ }^{279}$ In 1796, Washington refused Congress's request for the executive branch's files on the controversial treaty that John Jay had negotiated with the British in part on the grounds that the Philadelphia convention had rejected a proposal that all treaties be confirmed by statute. ${ }^{280}$ Powell dismisses these examples as

Virginia gentry to reestablish the Anglican Church after independence, in response to a perceived decline in public morals attributable to the contemporaneous deterioration of Anglican institutions in Virginia).

277 See Hans W. Frei, THE Eclipse of Biblical Narrative: A Study IN EiGHTEenth AND NineteEnTH CENTURY HeRMENEutics 51-54 (1974); ROBERT GRANT With David Tracy, A SHORT History OF THE INTERPRETATION OF THE Bible 103-04 (2d ed. 1984).

${ }^{278}$ Brief No. 6 for Waddington, Rutgers v. Waddington (N.Y. City Mayor's Ct. 1784), in 1 GOEBEL, supra note 1 , at 391 .

${ }^{279}$ See 5 ThOMAS JEFFERSON, Opinion on the Constitutionality of a National Bank (1791), in The Writings of THOMAS JefFerson 284, 287 (Paul L. Ford ed,, 1895), discussed in Powell, supra note 13, at 914-15 \& nn.152-53.

${ }^{280}$ See 5 AnNals of CONG. 760-61 (1796), discussed in Powell, supra note 13, at 920-21. 
aberrational. ${ }^{281}$ But when such uses of history are considered in the context of the evidence from the Case of the Prisoners, it seems to be the case that invocations of intent were part of the discourse concerning constitutional interpretation from the very start of such discourse in the revolutionary era.

\section{Antiliteralism and Judicial Stance}

The Case of the Prisoners also shows that antiliteralist approaches to judicial review could differ significantly. On one hand, Randolph's approach is very deferential to the legislature. Thus, he wrote, "For if [the constitution's] spirit opposes the exclusion of the Senate, its words must be free from ambiguity and decided, or cannot have the supremacy." ${ }^{282}$ Unless the text of the constitution is clearly inconsistent with the statute, the statute will be constitutional. Randolph's conception of a constrained scope of judicial review is consistent with the one that Professor James Bradley Thayer was to adopt in 1893 in his essay, The Origin and Scope of the American Doctrine of Constitutional Law, ${ }^{283}$ which profoundly influenced, among others, Justices Holmes, Brandeis, and Frankfurter, ${ }^{284}$ as well as Judge Learned Hand, ${ }^{285}$ and which Frankfurter called the most important law review article on American constitutional law ever written. ${ }^{286}$ Thayer catalogued the language of early judicial review cases concerning when a statute should be held invalid and noted that the cases repeatedly stated that statutes should not be held unconstitutional unless they clearly violated the constitution. ${ }^{287}$ He stated that this approach was first "foreshadowed" ${ }^{288}$ by Pendleton's opinion in the Case of the Prisoners, declar-

${ }^{281}$ See Powell, supra note 13, at 920-21 (discussing criticism of Washington for invocation of original intent and stating that Madison's response to Washington's act was one of "amazement"); id. at 915 n.153 (referring to "Jefferson's unusual resort to 'legislative history' from the Philadelphia convention's nominally secret proceedings").

${ }^{282}$ Randolph, supra note 8 , at 6 .

${ }^{283}$ Thayer, supra note 3.

${ }^{284}$ See Wallace Mendelson, The Influence of James $B$. Thayer upon the Work of Holmes, Brandeis, and Frankfurter, 31 VAND. L. REV. 71 (1978). For recent analyses of Thayer's work, see Symposium, One Hundred Years of Judicial Review: The Thayer Centennial Symposium, 88 Nw. U. L. REV. 1 (1993).

${ }^{285}$ See Gerald Gunther, Learned hand: The Man and the Judge 118-19 (1994).

${ }^{286}$ See Harlan B. Phillips, Felix Frankfurter Reminisces 299-301 (1960).

${ }^{287}$ See Thayer, supra note 3, at 138-42.

${ }^{288}$ Id. at 140. 
ing that the legitimacy of judicial review was a "deep, important, and, I will add, a tremendous question, the decision of which would involve consequences to which gentlemen may not ... have extended their ideas." ${ }^{289}$ Drawing on the early cases, Thayer then framed a deferential rule of judicial review that he argued should continue to guide judicial assertions of the power to invalidate statutes: "[A court] can only disregard the Act when those who have the right to make laws have not merely made a mistake, but have made a very clear one,-so clear that it is not open to rational question." 290

The notion that the early theories of judicial review involved a high degree of deference to legislatures has more recently been championed by Professor Sylvia Snowiss. In her book Judicial Review and the Law of the Constitution, ${ }^{291}$ the most complete study of early conceptions of judicial review, Snowiss contends that, in the period before Marbury, judicial review theory and practice were "to confine the concededly unconstitutional act, to circumstances where it was agreed that the legislature had 'in fact' violated the constitution." ${ }^{292}$ Again, Randolph's argument exemplifies this view.

Tucker's argument, however, does not. Tucker's conception of judicial review is aggressive. Statutes can be held unconstitutional if they violate the "spirit" of the constitution. The judiciary is the "Guardian" of the constitution. Admittedly, Tucker states that, "If any act thereof shall be found absolutely and irreconcilably contrary to the Constitution, it can not admit of a Doubt that such act is absolutely null and void," 293 suggesting that "irreconcilabl[e]" contradiction is necessary for an act to be judicially pronounced unconstitutional. But, as Tucker's argument demonstrates, "irreconcilabl[e]" contradiction can occur simply because a statute violates the spirit of the constitution. The deceptive character of Tucker's rhetoric suggests that, in some of the cases relied on by Thayer, judicial claims that statutes would not be held unconstitu-

${ }^{289}$ Id. at 140 (quoting Pendleton's opinion in Commonwealth v. Caton, 8 Va. (4 Call) $5,17(1782))$.

290 Id. at 144.

${ }^{291}$ SNOwiss, supra rote 4.

${ }^{292}$ Id. at 34. Professor Robert Clinton has offered another way of viewing the cases prior to the Federal Constitutional Convention as embodying a constrained conception of judicial review. By his count, four of the six cases involved the right to a trial by jury, and he suggests that the primary focus of the early cases was on protecting judicial independence from legislative interference. See CLINTON, supra note 3 , at $54-55$.

${ }^{293}$ Tucker, supra note 8 , at 9 . 
tional in "doubtful" cases may not in fact mean that those courts read the power of judicial review narrowly.

More basically, Tucker's argument in the Case of the Prisoners suggests the presence, in early discussions of judicial review, of a conception of judicial review that is far broader than that described by Thayer and Snowiss. While it is beyond the scope of this Article to trace this alternative tradition of broad judicial review, the 1793 case of judicial review Kamper $v$. Hawkins, ${ }^{294}$ the next case in which a Virginia court confronted an unconstitutional statute, illustrates that Tucker's argument in the Case of the Prisoners was not an aberrational statement of a young attorney. In Kamper, all five members of the Virginia General Court held unconstitutional a 1792 statute that gave district courts equitable powers. In their opinions, two of the Kamper judges adopted broad views of judicial review. ${ }^{295}$ One, not surprisingly, was Tucker, who had ascended to the bench in $1788 .^{296}$

Tucker's view of judicial review remained consistent with his view at the time of the Case of the Prisoners. Indeed, several weeks after he issued his opinion in Kamper, he re-read his notes of his argument in the Case of the Prisoners and wrote on the jacket: "Upon reviewing [my notes] at the distance of eleven years I find I have not changed my opinion ...." ${ }^{297}$ Echoing his argument in the Case of the Prisoners, Tucker in Kamper appealed to "the text of the constitution, and the spirit of our government." ${ }^{298}$ He noted that the legislature had repealed statutes that were "contrary to the true

2943 Va. (1 Va. Cas.) 20 (1793). For an excellent discussion of the different conceptions of judicial review in the case, see H. Jefferson Powell, The Uses of State Constitutional History: A Case Note, in TOWARD a USABLE PAST: LIBERTY UNDER STATE. Constitutions 196 (Paul Finkelman \& Stephen E. Gottlieb eds., 1991). The only instances between the Case of the Prisoners and Kamper in which a Virginia court evaluated the constitutionality of a statute were the Cases of the Judges of the Court of Appeals, $8 \mathrm{Va}$. (4 Call) 135 (1788). In the principal opinion, the court of appeals pronounced a state statute imposing additional duties on judges without additional compensation an "infraction of the constitution." Id. at 146. 'This opinion, however was not the product of a litigated case; it was merely a judicial pronouncement, sua sponte, on a recently passed statute. See infra text accompanying notes 325-26.

${ }^{295}$ See Kamper, 3 Va. (1 Va. Cas.) at 29-42, 66-97 (wherein both Judge Roane and Judge Tucker espoused broad judicial review).

${ }^{296}$ See CULlEN, supra note 8, at 75.

${ }^{297}$ Tucker, supra note 8 (note on jacket). He added that "the haste with which it was formed produced several inaccuracies which at this day perhaps $I$ might have avoided," but did not specify what those inaccuracies were. Id.

${ }^{298}$ Kamper, 3 Va. (1 Va. Cas.) at 68 (Tucker, J.). 
spirit of the constitution." 299 Nonetheless, he again saw the judiciary as uniquely entrusted with the protection of the constitution. "[T]he duty of expounding [the constitution]," he wrote at one point, "must be exclusively vested in the judiciary. ${ }^{300}$ At another point, Tucker observed that "the principles of our government have established the judiciary as a barrier against the possible usurpation, or abuse of power in the other departments. ${ }^{301}$

In his decision in Kamper, Judge Spencer Roane, whom legend asserts Thomas Jefferson would have named Chief Justice had John Adams not placed John Marshall on the bench in the waning days of Adams's administration, ${ }^{302}$ similarly took an expansive view of the judicial role. At greater length than Tucker, Roane invoked the spirit of the constitution as the basis for an assertion of judicial review:

[T] he judiciary may and ought to adjudge a law unconstitutional and void, if it be plainly repugnant to the letter of the Constitution, or the fundamental principles thereof. By fundamental principles, I understand, those great principles growing out of the Constitution, by the aid of which, in dubious cases, the Constitution may be explained and preserved inviolate; those land-marks, which it may be necessary to resort to, on account of the impossibility to foresee or provide for cases within the spirit, but without the letter of the Constitution. ${ }^{303}$

Roane, therefore, very clearly took the position that a statute could be unconstitutional if it violated the spirit of the constitution, even though it was consistent with the constitutional text.

Because of this emphasis on the spirit in interpreting constitutional text, the Case of the Prisoners and Kamper also bear on a theory of judicial review very different from Thayer's and Snowiss's, the theory offered by Professor Suzanna Sherry. While Thayer and Snowiss have stressed the constrained quality of early judicial review, Sherry has sought to create an originalist basis for a more activist judiciary by stressing the natural law dimension of the

${ }^{299}$ Id. at 76 (quoting Virginia statute).

${ }^{300}$ Id. at 79 .

${ }^{301}$ Id. at 87.

302 See Margaret E. Horsnell, Spencer Roane: Judicial Advocate of JEFFERSONIAN PRINCIPLES 33-34 (1986) (noting the legend, although suggesting "there is reason to doubt [it]").

${ }^{\text {sos }}$ Kamper, 3 Va. (1 Va. Cas.) at 40 (Roane, J.). 
cases decided prior to the Federal Constitutional Convention and by arguing for the revival of natural law. ${ }^{304}$ In developing her historical arguments, she separates judicial review cases decided under a constitution from those decided under extraconstitutional law. "Where the written constitution affirmatively addressed a problem-most of ten in governmental structure cases such as Caton, but even in cases, such as Bayard, where the constitution provided clear protection of individual rights-it was dispositive, but in other cases, judges looked outside the written constitution. ${ }^{n 03}$ The Case of the Prisoners and Kamper suggest that this bifurcation is too rigid. Invocations of the spirit in these structural cases decided under written constitutions indicate that extraconstitutional sources could inform even such cases. At the same time, the evidence offered here supports an end similar to Professor Sherry's. She has written: "Especially in the cases furthest from the constitutional language, this tacit preference for textual constitutionalism over natural law concepts undermines the Court's decision by allowing critics to attack the decision using the Court's own criteria of decision making," 306 and she offered the criticism of Roe $v$. Wade ${ }^{307}$ as an example. To the extent that Sherry's concern is with providing an historical basis for judicial activism that looks beyond the letter of the Constitution, Tucker and Roane provide such a basis, although, rather than invoking natural law, they were taking the position that courts could read a written constitution broadly.

The evidence discussed here from the Case of the Prisoners and Kamper is obviously far too limited to support a conclusion as to what theories of judicial review were dominant at the birth of the nation. My point here is simply to highlight the range of arguments available. Powell's work has previously revealed the presence of a textualist approach. What the Case of the Prisoners (supported by Kamper) demonstrates is the presence of an antiliteralist approach to judicial review, and it also demonstrates that that approach, in turn, could support both judicial deference (as with Randolph) and assertiveness (as with Tucker and Roane).

\footnotetext{
${ }^{304}$ See Sherry, supra note 1 , at $1176-77$.

${ }^{305}$ Id. at 1145-46; see also supra note 12 (discussing Bayard).

${ }^{306}$ Sherry, supra note 1 , at 1176.

${ }^{307} 410$ U.S. 113 (1973).
} 


\section{B. Chief Justice Marshall and the Origins of Judicial Review}

Historian Charles Beard began his classic 1912 article on judicial review, The Supreme Court-Usurper or Grantee?, with the question, "Did the framers of the federal Constitution intend that the Supreme Court should pass upon the constitutionality of acts of Congress?" 308 After reviewing the evidence bearing on this question, he concluded the piece with the statement: "[I]t is difficult to understand the temerity of those who speak of the power asserted by Marshall in Marbury v. Madison as 'usurpation.' $\$ 309$ The linkage is typical. Traditionally, scholars have treated as inextricably joined the question whether Marshall acted in good faith in proclaiming judicial review in Marbury and the question whether the Framers intended judicial review.

In seeking to determine original intent about judicial review, academics have looked primarily to the debates in Philadelphia, to the state ratifying debates (where, outside of Virginia, the topic provoked relatively little comment), to the early cases in which courts confronted the issue of whether they had the power to invalidate statutes, and to the popular reactions to those decisions. The comments made in Philadelphia have been parsed very differently, although there is general agreement that, to the extent the matter was reflected on, federal judicial review of state legislation was deemed necessary to insure consistency with the United States Constitution. At the same time, scholars have often stressed that judicial review was controversial at the time the Constitution was framed. ${ }^{310}$

In large part, the evidence for the conclusion that judicial review was not generally accepted is that the cases on which scholars have traditionally focused-Rutgers $v$. Waddington, ${ }^{311}$ Trevett $v$. Weeden, ${ }^{312}$ and Bayard $v$. Singleton ${ }^{313}$-are cases in which the decisions proved controversial. (These cases have been the center of attention because, until this Article, they were the ones about which

${ }^{308}$ Charles A. Beard, The Supreme Court-Usurper or Grantee?, 27 POL. SCI. Q. 1, 1 (1912).

${ }^{309}$ Id. at 34 .

${ }^{310}$ See e.g., LEVY, supra note 4, at 89-123 (discussing evidence on judicial review and the original understanding and scholarly debate on the subject).

${ }^{311}$ N.Y. City Mayor's Ct. 1784, reprinted in 1 GOEBEL, supra note 1, at 392-419.

${ }^{312}$ R.I. 1786, described in VARNUM, supra note 1.

3131 N.C. (Mart.) 48 (1787). 
the most was known. ${ }^{314}$ ) When Judge Duane, the judge in Rutgers, construed New York's Trespass Act in a way that avoided conflict between it and either the law of nations or the common law, but that was inconsistent with its apparent meaning, a group of individuals, including prominent politician Melancton Smith, published a sharp criticism of the holding in the newspaper The New York Packet. ${ }^{315}$ Additionally, the New York Assembly denounced the decision and made an unsuccessful attempt to oust the judge from office. ${ }^{316}$ When the judges in Trevett dismissed the case after the defendant had challenged the Rhode Island Paper Money Act, the Rhode Island legislature summoned the judges in Trevett to determine the basis for the dismissal. When one judge argued that the statute was unconstitutional (although he also stated that the court's judgment had simply been that the statute was not "cognizable") and another spoke in favor of judicial independence, the legislature voted that it was not satisfied with the answers provided. At the next election, the legislature ousted four of the five judges who had sat on the provided case, reelecting only the judge who had been able to avoid stating his reasons for voting in the defendant's favor. ${ }^{317}$ In contrast, there was no legislative reprimand when the court in Bayard held unconstitutional a statute that barred Tories from bringing suit to recover their confiscated properties, but even that case suggests significant opposition to judicial review. When the court initially delayed reaching a decision in the case, its members were called before the North Carolina legislature to determine if they were guilty of malpractice in office by disregarding a statute (although a determination was made not to impeach them). ${ }^{318}$ James Iredell's publication of his argument in favor of judicial review met with the famous response of Richard Spaight, one of North Carolina's representatives to the Federal Constitutional Convention, attacking judicial review. ${ }^{319}$ Even in North Carolina, then, the assertion of judicial review was associated with

314 See supra notes 20-22 and accompanying text.

${ }^{315}$ See 1 Goebel, supra note 4, at 137 n.138 (“That there should be a power vested in courts of judicature, whereby they might control the supreme Legislative power we think is absurd in itself. Such power in courts would be destructive of liberty, and remove all security of property." ).

${ }^{316}$ See id. at 137.

${ }^{317}$ See id. at 140-41.

${ }^{318}$ See LeVY, supra note 4 , at 98.

${ }^{319}$ See Letter from Richard Spaight to James Iredell (Aug. 12, 1787), in 2 MCREE, supra note 91 , at $168,168-70$. 
controversy, although of a less serious dimension than in either New York or Rhode Island. More broadly, scholars' focus on these three cases is probably responsible in large part for the accepted view that, to quote Professor Leonard Levy, the early judicial review precedents "show that it was nowhere established, indeed that it seemed novel, controversial, and an encroachment on legislative authority. Its exercise, even when imagined, was disputed and liable to provoke the legislature to retaliation. ${ }^{320}$

Judicial review, however, was accepted in Virginia at the time of the convention. The Case of the Prisoners suggests Virginia's amenability to judicial review. According to Randolph, the initial reaction of the general court was to assert the power to invalidate statutes. In the court of appeals, two judges explicitly declared that they had the power to review statutes for constitutionality-probably the first judges in revolutionary America to hold that they had this power-and there was no adverse legislative response. The House of Delegates voted to amend the challenged statute. While the Senate did not concur, that decision did not represent defiance of the court of appeals, since the court had held the statute constitutional. For challenging the legislature's authority, the prisoners, rather than being punished, benefitted, because both houses then voted to pardon them. No ongoing controversy existed for the papers to report. The matter had become one of "small moment," to quote Pendleton. ${ }^{321}$ That Randolph felt duty bound to embrace judicial review at the expense of the prosecution's case simply highlights the fact that in 1782 in Virginia judicial review was a mainstream position.

There is a counterargument to all of this: the absence of controversy may be a product of the fact that the prisoners, after all, completely lost their case-whereas the parties challenging the state statutes in Bayard, Rutgers, and Trevett all at least partially achieved the ends they sought. The subsequent history of judicial review in Virginia makes clear, however, that the prisoners' loss should not obscure Virginia's uniquely rapid acceptance of judicial review. Of course, that consensus was not universal. Madison, to cite the most prominent example, continued to wrestle with the legitimacy of judicial review. ${ }^{322}$ Nonetheless, judicial review appears to have

${ }^{320}$ LEVY, supra note 4 , at 99.

${ }^{321}$ Letter from Edmund Pendleton to James Madison(Dec. 9, 1782), in 5 MADISON PAPERS, supra note 8, at 382.

${ }^{322}$ See Charles F. Hobson, The Negative on State Laws: James Madison, the 
gained broad approval very early. After the Case of the Prisoners, a Virginia court next addressed the legitimacy of judicial review in 1788, when the court of appeals issued "The Respectful Remonstrance of the court of appeals, ${ }^{n 23}$ written by Chancellor Pendleton. ${ }^{324}$ Earlier that year, the legislature had passed a district court bill requiring the judges of the court of appeals to sit on the district court twice a year and providing no additional salary for these new obligations. Although the statute was not challenged in a case, the court of appeals nevertheless issued the Remonstrance. It stated that the statute violated the Virginia Constitution because the additional imposition of responsibilities without additional money was effectively a constitutionally prohibited diminution in judicial salary. ${ }^{325}$ The legislature responded by first suspending the challenged bill and then passing a court reorganization bill designed to meet the concerns of the judges. ${ }^{326}$

Kamper $v$. Hawkins, ${ }^{327}$ the 1794 decision in which the court of appeals unanimously concluded that a 1792 act gave the district courts equitable powers, has already been discussed. ${ }^{328}$ Unlike the Remonstrance, this was an actual case, one that turned on whether the district court could legitimately exercise its statutorily vested powers. This unanimous decision reflects the acceptance of judicial review among the members of the judiciary. Its acceptance among members of the populace is indicated by the fact that the court ultimately prevailed, creating a separate system of superior chancery courts later that year. ${ }^{329}$

Constitution, and the Crisis of Republican Government, 36 WM. \& MARY Q. 215, 229-30 (1979) (discussing Madison's concerns about judicial review); Ralph L. Ketchain, James Madison and Judicial Review, 8 SyRACUSE L. REv. 158, 159 (1957) (cxamining Madison's early vacillation regarding the issue of judicial review).

With respect to the other leading Virginian political thinker, it should be added that after 1800 , Jefferson retreated from his earlier support of judicial review, perhaps in response to Federalist control of the judiciary. $\rightarrow$ Wallace Mendelson, Jefferson on Judicial Review: Consistency Through Change, 29 U. CHI. L. REv. 327, 330-32 (1962).

${ }^{323} 8$ Va. (4 Call) 135 (1788).

${ }^{324}$ See Charles F. Hobson, Introduction to 5 MARSHALl PAPERS, supra note 15 , at xxiii, xxxi-xxxii.

${ }^{325}$ See 8 Va. (4 Call) at 141-47. The Cases of the Judges, as reported by Call, set forth a number of related judicial acts. For the judicial protest that followed the initial legislative response to the Remonstrance, see $8 \mathrm{Va}$. (4 Call.) at 148-50.

${ }^{326}$ See CuLLEN, supra note 8, at 78-81 (discussing the history of the Remonstrance); Note to Letter from Charles Lee to George Washington (May 14, 1788), in 9 DOCUMENTARY HISTORY, supra note 58 , at 797, 797-98 n.2 (same).

3273 Va. (1 Va. Cas.) 20 (1794).

${ }^{328}$ See supra part II.A.3.

${ }^{329}$ See Powell, supra note 294, at 205. 
Virginia's broad, early acceptance of judicial review is also indicated by Turpin $v$. Locket, ${ }^{330}$ a case roughly contemporaneous with, though decided the year after, Marbury. At issue in Turpin was a controversial Virginia statute that provided for glebe lands, traditionally the property of the Episcopalian Church, to be sold to benefit the poor. Church vestrymen challenged the statute's constitutionality, but Chancellor Wythe ruled against them and upheld the statute. The vestryman then appealed to the Virginia Court of Appeals, which voted internally, three to one, with Spencer Roane dissenting, that the statute was unconstitutional. Pendleton drafted the majority opinion, but he died the day he was to deliver it, leaving the fate of the statute in the hands of the judge who would be named to replace him. If that judge were to vote that the statute was unconstitutional, it would be overturned; if Pendleton's successor were to vote that the act was constitutional, the court would be deadlocked, and Wythe's opinion in favor of the statute would control. ${ }^{331}$

The state legislature was anxious that the law be upheld. Tucker, still a judge of the general court, was approached and asked how he would vote on the question if he were named to the court of appeals. He wrote in response that it was improper for him to comment on a pending case and that he could not bind himself in advance to a vote one way or the other. He did, however, refer his questioner to a section of his treatise, in which he had approved of a plan before the Virginia legislature that imposed taxes to provide for religious education; he suggested that his stance in Turpin could be inferred from that passage. ${ }^{332}$ Charles Cullen, Tucker's biographer, wrote about the incident:

When Tucker referred [his correspondent] to his essay he was sincere in believing that his mind was not unalterably made up concerning the pending case before the Court of Appeals, but at the same time he was aware that any legislator could see that he thought the state had the right to use its powers for the benefit of its citizens .... If he supported this plan [discussed in his treatise] for the benefit of Virginia, he most likely would favor the sale of vacant glebe lands when the proceeds were to be used to benefit its citizens. ${ }^{339}$

s30 10 Va. (6 Call) 113 (1804).

${ }^{331}$ See 2 MAYs, supra note 6, at $337-45$ (discussing the case).

${ }^{332}$ See CULLEN, supra note 8 , at $175-77$. For the relevant section of Tucker's treatise, see 1 TUCKER, supra note 1, at 113-18.

${ }^{339}$ CULLEN, supra note 8, at 177. 
Tucker was duly named to the court, where he joined Roane in upholding the statute's constitutionality. The two-to-two vote of the court of appeals left in place Wythe's opinion upholding the statute. $^{334}$

The episode obviously shows that legislators were willing to manipulate the appointment process in order to have a statute upheld. For the purposes of this study, it shows, more importantly, the degree of consensus around judicial review in Virginia at the time of Marbury. The safest course of action for legislators who wanted the statute to be upheld would have been to secure the appointment of an opponent of judicial review. That their choice was an individual who had repeatedly asserted his belief in judicial review (one time as a member of a court that invalidated a statute) and who, although he hinted that he would uphold the statute, was unwilling to give a flat assurance that he would do so indicates that in 1803 no plausible candidates for the court opposed judicial review.

The most striking evidence of the early consensus in favor of judicial review is that every member of the state ratifying convention in 1788 who took a position on the legitimacy of judicial review spoke in its favor, and that these speakers covered a broad political spectrum. For example, Federalist leader George Nicholas explained that because of judicial review there was no need to be concerned that Congress would exceed its powers under the Constitution. "[W]ho is to determine the extent of such [congressional] powers?" he asked rhetorically, and answered, "I say, the same power which in all well regulated communities determines the extent of Legislative powers-If they exceed these powers, the Judiciary will declare it void." 335 Having recently written the decision in the Cases of the Judges, Chancellor Pendleton, a Federalist, noted that the Virginia state legislature had passed unconstitutional statutes and added, "My brethern [sic] in that department (the judicial) felt great uneasiness in their minds, to violate the Constitution by such a law. They have prevented the operation of some unconstitutional acts. ${ }^{336}$ Leading Anti-Federalist Patrick Henry responded, "The Honorable Gentleman did our Judiciary honour in saying, that they had firmness to counteract the Legislature in some

\footnotetext{
${ }^{334}$ See Turpin, 10 Va. (6 Call) at 128 (Tucker, J.); id. at 157 (Roane, J.).

${ }^{335} 10$ DOCUMENTARY HISTORY, supra note 58, at 1327.

${ }^{936}$ Id. at 1197 (footnote omitted).
} 
cases. Yes, Sir, our Judges opposed the acts of the Legislature. . . They had fortitude to declare that they were the Judiciary and would oppose unconstitutional acts. ${ }^{\text {397 }}$ John Marshall himself was unambiguous:

If [Congress] were to make a law not warranted by any of the powers enumerated, it would be considered by the Judges as an infringement of the Constitution which they are to guard:-They would not consider such a law as coming under their jurisdiction.They would declare it void. ${ }^{338}$

Why Virginians were so supportive of judicial review is a question that invites speculation. ${ }^{339}$ The answer, in part, may be that lawyers in Virginia, and the South in general, occupied a different place in the political and social structure than they did in northern states such as New York and Rhode Island, where judicial review proved particularly controversial. As historian Maxwell Bloomfield observed, "The distinctive life-style of the southern lawyer [enabled him] . . . to appeal to community sympathies [more] than his more professionalized northern prototype." ${ }^{340}$ Lawyers in the North, although claiming to be independent professionals above the market, were typically dependent on the law for their livelihood. Thus, Alexander Hamilton, the lawyer in Rutgers, found it necessary at times to leave public life and return to his law practice to make money. ${ }^{311}$ Because law provided their source of

${ }^{337}$ Id. at 1219 (footnote omitted).

${ }^{338}$ Id. at 1431; see also 9 id. at 1101 (Edmund Randolph opining that a good judiciary stands in the way of an oppressive Congress); $10 \mathrm{id}$. at 1361 (George Mason arguing that the federal judiciary has the duty and power to declare ex post facto laws unconstitutional); id. at 1420-21 (Patrick Henry asserting that federal courts would not allow Congress to prohibit appeals as to facts); id. at 1427 (Edmund Pendleton stating that the Constitution prohibits oppressive laws and that "honest independent Judges will never admit an oppressive construction"); $i d$. at 1448 (William Grayson noting that judges are expected to defend the Constitution against abridgement by Congress).

${ }^{339}$ The theories advanced here on why judicial review won acceptance in Virginia represent tentative suggestions. I intend to explore more systematically the issue of why Virginians and others responded to judicial review in the way that they did in the larger study of which this is a part. See supra note + .

${ }^{340}$ Maxwell Bloomfield, American Lawyers in a Changing Society, 17761876, at 50-51 (1976). Similarly, contrasting lawyers in the North and South, historian E. Lee Shepard has observed that "[t]he successful lawyer-planter, falling heir to a tradition of local dominance by a social elite, found favor with many of his non-professional neighbors." E. Lee Shepard, Lawyers Look at Themselves: Professional Consciousness and the Virginia Bar, 1770-1850, 25 AM. J. LEGAL. HIST. 1, 10 (1981).

${ }^{341}$ See Gordon S. WOOd, The RAdiCAlism of the AMERICAN Revolution 345-46 (1992) (describing Hamilton's self-image as a gentleman-lawyer). 
income, lawyers were a distinct economic interest group, and one that other politically powerful interest groups, such as merchants and farmers, would not want to have supervise the political process through judicial review.

In contrast, Virginia lawyers, like lawyers in other parts of the South, were typically planters for whom the law resembled an avocation. Thus, the lawyer-planter Thomas Jefferson lauded law for its value in politics and in service to the community: "[The study of law] qualifies a man to be useful to himself, to his neighbors, and to the public. It is the most certain stepping stone to preferment in the political line. ${ }^{n 42}$ Historian F. Thornton Miller has recently observed: "[F]ew lawyers and judges wished to desert the heritage that gave social prestige in the Old Dominion. Either the plantation was not given up upon pursuing a legal career, or, if one did gain wealth through a law practice, a plantation was acquired." 343 The lawyers whose notes have been discussed herein illustrate this concept of lawyer as gentleman. Born to wealth, Randolph, in addition to being a successful lawyer, owned a number of plantations. ${ }^{344}$ Trained as a lawyer, Tucker did not actually begin to practice until he had achieved wealth through trade and through marriage to a widow who owned three plantations, which he then ran for several years. ${ }^{345}$ Rather than presenting a challenge to the planter elite, such lawyers were part of it.

Thus, the differing nature of legal practice may in part explain why the initial response to judicial review was more favorable in the South (Virginia and North Carolina) than in the North (New York and Rhode Island). Beyond this, it appears that in Virginia the law played a particularly strong role in reinforcing the gentry's social and political control and this may account for the particular ease with which judicial review was accepted in the state. "Command of the law," historian Rhys Isaac has written, "sustained this social

${ }^{342}$ Letter from Thomas Jefferson to Thomas Mann Randolph, Jr. (May 30, 1790), in 16 The PAPERS OF ThOMAS JefFERSON 449 (Julian P. Boyd et al. eds., 1961); see also Woon, supra note 341 , at 346 (discussing this remark and the concept of law as an avocation).

${ }^{343} \mathrm{~F}$. Thornton Miller, JUdges and JuRIes Versus the LAW: Virginia's Provincial Legal Perspective, 1783-1828, at 107 (1994); see also A.G. Roeber, FaITHFul MaGistrates and RePUblican LaWyers: Creators OF Virginia Legal Culture, 1680-1810, at 53 (1981) (commenting on the "fluid and ill-defined boundaries between offices and occupations of 'planter,' 'lawyer,' 'merchant,' and so

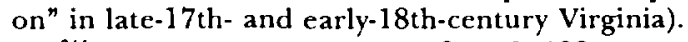

${ }^{344}$ See REARDON, supra note 9, at 3, 193.

${ }^{345}$ See Cullen, supra note 8, at 20-23. 
supremacy of the gentry, ${ }^{346}$ and to illustrate this point he quotes the satirist James Reid, "[The gentry] diligently search the Scriptures, but the scriptures which they search are the Laws of Virginia: for though you may find innumerable families in which there is no Bible, yet you will not find one without a Law-book." 347 Political control, legal control, and economic control were joined in a unitary elite. According to Isaac:

Under the old [colonial] regime the county courts had meshed closely with a House of Burgesses that was, in accordance with ancient traditions of authority, a county court writ large. Under the new form of [postrevolutionary] government ... the elected representatives continued to be drawn largely from among the justices of the county bench. ${ }^{948}$

This suggests that judicial review may have won easy acceptance in Virginia because the bench and bar were controlled by the same type of people (and to some extent the same people) who dominated the political process. Participants in the political process were favorably disposed towards the bench and bar, and towards judicial review. Thus, when Jefferson wrote Madison in 1789, his argument that there should be a judicially enforceable federal bill of rights was explicitly linked to his faith in the judgment of the members of the Virginia Court of Appeals:

In the arguments in favor of a declaration of rights, you omit one which has great weight with me, the legal check which it puts into the hands of the judiciary. This is a body, which if rendered independent, and kept strictly to their own department merits great confidence for their learning and integrity. In fact what degree of confidence would be too much for a body composed of such men as [court of appeals judges] Wythe, Blair, and Pendleton? On characters like these the "civium ardor prava jubentium" would make no impression. ${ }^{349}$

All of this suggests an alternative view of Marshall and Marbury. Scholars typically discuss the judicial review aspect of Marbury in

${ }^{346}$ ISAAC, supra note 276 , at 133 .

${ }^{347}$ Id.

${ }^{348}$ Id. at 320.

${ }^{349}$ Letter from Thomas Jefferson to James Madison (Mar. 15, 1789), in 14 PAPERS OF THOMAS JEFFERSON, supra note 342 , at 659,660 . The Latin reference is to Horace: "Justum et tenacem propositi virum/non civium ardor prava iubentium," HORACE: THE ODES AND EPODES 178 (C.E. Bennett trans., rev. ed. 1968), which translates as, "The man tenacious of his purpose in a righteous cause is not shaken from his firm resolve by the frenzy of his fellow-citizens bidding what is wrong." Id at 179. 
one of two ways. The more familiar view-the one that Professor Robert Clinton in his recent study of judicial review and Marbury observes has "remained the starting point for discussion ... in the modern era"350-situates Marbury in the context of the political struggles, at the start of the Jefferson administration, between the Republican legislature and executive and the Federalist judiciary that was seeking to check the other branches of government. When William Marbury brought suit in the United States Supreme Court seeking a writ of mandamus directing Secretary of State James Madison to deliver to him the Justice of the Peace commission that President Adams had signed on his last day in office, Marshall was placed in a seemingly impossible situation. According to Professor Robert McCloskey:

If [Marshall and his Court] upheld Marbury and ordered delivery of the commission, the order would surely be ignored by Madison, the Court would be exposed as impotent to enforce its mandates, the shakiness of judicial prestige would be dramatically emphasized. If on the other hand they did not uphold Marbury, they would give aid and comfort to Jefferson and might seem to support his denunciation of the "midnight appointments. ${ }^{\text {p951 }}$

Marshall's masterstroke was to hold unconstitutional Section 13 of the Judiciary Act of 1789 , the statutory provision providing that the Supreme Court had original jurisdiction in the matter. Thus he established judicial review, which the Federalists devoutly desired, while giving the Republicans the result they wanted (a loss for Marbury) and overturning legislation that the Federalists had enacted in the first place. McCloskey writes:

The decision was criticized for its dictum that the executive could be called to account by judicial process, but since the requested writ was in fact denied, no really great heat was generated even on this point. And as for the argument for judicial review, at the time only the Federalists paid much attention to it, and they of course were warmly approving. ${ }^{932}$

${ }^{350}$ Clinton, supra note 3, at 219. See generally id. at 211-23 (discussing 20thcentury interpretations of Marbury); James M. O'Fallon, Marbury, 44 STAN. L. REv. 219, $219-20$ n.3 (1992) (describing Robert McCloskey's view of Marbury, discussed at infra text accompanying notes 351-52, as accepted by students as "dogma"). O'Fallon's article is a recent example of a work that stresses the political dimensions of Marshall's opinion, although O'Fallon departs from the standard view by emphasizing the defensive quality of Marshall's position.

${ }^{351}$ Robert G. MCCloskey, The American Supreme Court 41 (1960).

${ }^{352}$ Id. at 43. 
Marbury is thus, to quote Professor Clinton, a kind of "coup d'etat, engineered for political purposes. ${ }^{\text {"353 }}$

The alternate (and not necessarily inconsistent) view of Marbury is that Marshall's embrace of judicial review was correct on originalist grounds. Charles Beard has offered the classic historical defense of this position. ${ }^{354}$ Professor Felix Frankfurter proclaimed Beard's analysis of Framers' contemporaneous statements about judicial review dispositive, ${ }^{355}$ and Alexander Bickel, in rejecting the claim that Marbury involved "usurpation," also invoked Beard and stated:

[I]t is as clear as such matters can be that the Framers of the Constitution specifically, if tacitly, expected that the federal courts would assume a power-of whatever exact dimensions-to pass on the constitutionality of actions of the Congress and the President, as well as of the several states. ${ }^{\text {936 }}$

Similarly, Professor Clinton has recently written, "[T]he Court's refusal to apply Section 13 in Marbury was consistent with Lockean values, existing legal precedent, and the theory of judicial function embodied in the Constitution. ${ }^{357}$

The Case of the Prisoners and the early history of judicial review in Virginia suggest a different way both to view the case and to read Marshall's opinion: Marshall was the product of a legal and political culture that was particularly amenable to judicial review-indeed, from all appearances, uniquely amenable to judicial review. It should be noted at the outset that the sketchy quality of the preserved Marshall papers-for example, departing from convention, he did not keep copies of his own correspondence-makes it impossible to trace with certainty the evolution of Marshall's thinking about judicial review. ${ }^{358}$ Nonetheless, consideration of Marshall in the context of the history of judicial review in his home state is illuminating. ${ }^{359}$

${ }^{353}$ Clinton, supra note 3, at 219.

354 See Charles A. Beard, The Supreme Court and the Constitution 46-82, 108-118 (1912) (analyzing Marbury and the evidence at the time of framing concerning judicial review).

${ }^{355}$ See Felix Frankfurter, A Note on Advisory Opinions, 37 HARv. L. Rev. 1002, 1003 n.4 (1924).

${ }^{956}$ Alexander M. Bickel, The Least Dangerous Branch: The Supreme CourT AT THE BAR OF POLITICS 15 (1962).

${ }^{357}$ Clinton, supra note 3 , at 103

${ }^{958}$ See Introduction to 1 MARSHALL. PAPERS, supra note 15 , at xix, xxi.

${ }^{359}$ For an earlier and interesting attempt to place Marshall's thought more 
Marshall received his legal education at the College of William and Mary in 1780 under George Wythe. ${ }^{360}$ Wythe delivered the eloquent statement in favor of judicial review in the Case of the Prisoners previously discussed and, as also previously noted, it appears that Marshall was in the courtroom when that opinion was delivered. ${ }^{361}$ It is noteworthy that, while Wythe trained only a relatively small part of the Virginia bar-under 200 lawyers-he educated not only Marshall, but Jefferson, Tucker, and Roane, all of whom were important early champions of judicial review. ${ }^{962}$ More broadly, Wythe and, to an even greater extent, Pendleton were Marshall's role models, and, before the Federal Constitutional Convention, each had written a pro-judicial review opinion: Wythe's opinion in the Case of the Prisoners being matched by Pendleton's in the Remonstrance of the Judges. In Marbury, then, Marshall was following the path established years before by the jurists whom he most admired. ${ }^{363}$

Fully appreciating the link between Marshall's experience in Virginia with his decision in Marbury, however, requires more than a recognition of the fact that the judiciary in that state had asserted the power to review statutes well before Marbury. More important, it requires recognition of the fact that judicial review had been remarkably uncontroversial in that state. The Case of the Prisoners and its aftermath illustrate the acceptance of judicial review, an acceptance that arguably occurred because the legal and political structure of the state meant that vesting power in the judiciary to review statutes was not perceived as posing a threat to the political process. Thus, Marshall spent his career as a legal practitioner in an environment in which judicial review was relatively unproblematic, and he was shaped by a legal and political structure amenable to judicial review. Due to his Virginian background, Marshall, at the time of Marbury, must have found the question of judicial review to

generally in the context of his Virginia experience, see William E. Nelson, The Eighteenth-Century Background of John Marshall's Constitutional Jurisprudence, $76 \mathrm{MICH}$. L. REV. 893 (1978).

${ }^{360}$ See Charles T. Cullen, New Light on John Marshall's Legal Education and Admission to the Bar, 16 AM. J. LECAL HIST. 345, 345-46 (1972).

${ }^{361}$ See supra text accompanying note 15.

${ }^{362}$ See HORSNELL, supra note 302, at 5-6 (noting that Roane studied under Wythe); Carrington, supra note 11 , at 537 (stating that Jefferson and Tucker studied under Wythe).

${ }^{363}$ See Introduction to 5 MARShall. PAPERS, supra note 15, at xxiii, lvii-lviii (stating that Marbury was Marshall's attempt, at a national level, to replicate what Wythe's and Pendleton's decisions accomplished at the state level). 
be an old one-and one that, for him and for the legal and political community he knew best, had been resolved long before. The often-remarked upon "self-confiden[t]"-to use Professor McCloskey's term-tone of Marbury reflects this. ${ }^{364}$ In beginning the discussion of judicial review in that case, Marshall declared that to resolve the "question, whether an act repugnant to the constitution, can become the law of the land... [i]t seems only necessary to recognise certain principles, supposed to have been long and well established. ${ }^{365}$

For someone who had witnessed the Case of the Prisoners and its aftermath in Virginia, the principles that Marshall then enumerated-the superiority of the Constitution to a statute and the Court's power to disregard a statute in conflict with the Constitution ${ }^{366}-$ must have seemed "long and well established." "667

\section{CONCLUSION}

While the revolutionary-era cases in which courts were asked to decide whether they had the power to declare statutes unconstitutional have been the subject of constant study for over one hundred years, the notes of two of the attorneys who participated in the Case of the Prisoners-St. George Tucker and Virginia Attorney General Edmund Randolph-have escaped scrutiny. These documents provide our best evidence of how the framing generation believed a court should construe a constitution when determining whether to hold a statute unconstitutional. This Article uses those notes and other primary sources to construct a record of the case. That record is significant for two reasons. First, it provides evidence that the Framers of the Federal Constitution had available to them interpretive approaches that held that the subjective intent of the Framers was relevant to constitutional interpretation and that a constitution should be construed in accordance with its spirit, not just its text. Second, placing Marshall's decision in Marbury in the context of the Case of the Prisoners and early Virginia constitutional history-as opposed to in the context of national political and constitutional history-suggests that Marshall's commitment to judicial review can be understood as having been shaped by the fact

\footnotetext{
${ }^{364}$ MCCLOSKEY, supra note 351, at 42.

${ }^{365}$ Marbury v. Madison, 5 U.S. (1 Cranch) 137, 176 (1803)

${ }^{366}$ See id. at 178 .

${ }^{367} \mathrm{Id}$. at 176.
} 
that he was a citizen of the state in which judicial review won early and easy acceptance. 